WIRTSCHAFTSWISSENSCHAFTLICHES ZENTRUM (WWZ) DER UNIVERSITÄT BASEL

Juni 2006

\title{
The Intergenerational Transmission of Income in Switzerland A Comparison between Natives and Immigrants
}


The Author:

\section{Philipp Bauer}

Department of Economics (WWZ), University of Basel

Petersgraben 51

CH - 4051 Basel

philipp.bauer@unibas.ch

A publication of the Department of Economics (WWZ), University of Basel

Adress for information:

WWZ Forum, Petersgraben 51, CH-4003 Basel, Fax +416126733 33

The WWZ Research Papers document the results of research projects at the WWZ.

(C) WWZ Forum 2006 and the author. Reproduction for other purposes than the personal use needs the permission of the author and the WWZ Forum. Please contact: forum-wwz@unibas.ch. 


\title{
The Intergenerational Transmission of Income in Switzerland
}

\section{A Comparison Between Natives and Immigrants}

\author{
Philipp Bauer \\ (University of Basel)
}

25.06 .2006

This paper analyses the intergenerational income mobility for natives and immigrants in Switzerland. An IV approach based on data from two different data sets is used. As there is no adequate data on fathers, I revert to information from a period that differs from actual fathers' work period. This methodological approach leads to a bias of the resulting intergenerational elasticity. Nevertheless, cross-national comparison of income mobility is still possible. A comparison across subgroups of the Swiss population shows strong differences between Swiss and immigrants. Compared to natives, immigrants are more immobile. Also, substantial heterogeneity is found across different ethnic groups. Using quantile regression, mobility for natives is found to be similar for all income quantiles. Among immigrants, mobility is higher at the lower as well as at the upper end of the income distribution. These patterns differ from previous results from other countries.

Keywords: Income mobility, Intergenerational transmission, Immigrants

JEL Code: C23, I30, J61, J62

Philipp C. Bauer

WWZ - University of Basel

Petersgraben 51

4051 Basel

Switzerland

Phone: ++41 (0)61 2673386

Fax: ++41 (0)61 2673351

Email philipp.bauer@unibas.ch

I acknowledge the financial support from the Swiss Nation Science Foundations NRP 52 grant. I am very grateful for the help and support of Regina T. Riphahn. Further, I thank George Sheldon and Claudia Strub for helpful comments. 


\section{Introduction}

For almost three decades, economists have focused on the question how earnings are transmitted from one generation to the next. The degree to which an individual's income is affected by her parents' income is seen as a norm to evaluate the societal capability to provide equality of economic opportunity. A rich literature exists for the U.S., Great Britain, and the Scandinavian countries. Furthermore, some evidence has been provided for Canada, South Africa, Malaysia, Germany, and France (for an overview see Solon 1999, 2002). For the first time, this paper analyses intergenerational income mobility in Switzerland. Empirical research has already shown that Switzerland is characterized by strong immobility in the transmission of education. In a cross-national OECD study (OECD 2002), parental influence is highest in Switzerland for a child's educational attainment across 31 other countries (Zahner 2005). ${ }^{1}$ As education is probably the major mediating factor of mobility (Erikson and Goldthorpe 2002), it is to be expected that the intergenerational income transmission should also be very high in Switzerland.

In addition and analogous to Bauer and Riphahn (2005, 2006), who compared the educational transmission process for Switzerland between natives and immigrants, I identify differences in the intergenerational income transmission between natives and immigrants. This aspect has barely received attention in the literature of parent-child mobility. ${ }^{2}$ Typically, the intergenerational transmission process is considered to be identical for all individuals within a society. This is astonishing since different economists have already pointed out that a person's ethnic affiliation matters in determining her future labor market success (e.g. see Borjas 1993). Ethnicity might show the relevance of culture in the intergenerational transmission process. The relevance of ethnic differences in the equality of opportunity must not be underestimated. At present, almost every Western country is confronted with different and heterogeneous waves of immigration. For Switzerland, the share of residents without Swiss citizenship is more than $20 \%(\mathrm{BfS} 2005) .{ }^{3}$ For the last 50 years, about $70 \%$ of the rise in the Swiss population has been due to immigration (Haug 2002). Switzerland has always attracted blue collar workers as well as highly skilled immigrants. Blue collar workers are typically

\footnotetext{
${ }^{1}$ For Switzerland, Bauer and Riphahn (2005) have shown that a child's probability to attend an advanced school degree is about eight times higher for a child with highly educated parents compared to a child with badly educated parents.

${ }^{2}$ Regarding differences among ethnic groups, Mazumder (2001) finds higher elasticities among blacks compared to whites in the US. Also for Sweden, intergenerational earnings mobility is lower for immigrants in Sweden (Hammarstedt and Palme 2006). Aydemir et (2006) al. find no differences in the intergenerational earnings elasticities among immigrants compared to native Canadians.

${ }^{3}$ The share of foreign born residents is similar.
} 
handicapped by low education, poor language skills, and few economic opportunities in the job market.

The investigation of the impact of ethnicity on the intergenerational transmission is important as it shows how these differences in opportunities among immigrants change from one generation to the next, i.e. it shows whether a society is able to provide equality of opportunity for disadvantaged ethnic groups. This might inform policy decisions to diminish future disparity.

Studies of intergenerational income transmission typically measure the correlation between a son's and his father's income which requires data that includes both sons' as well as fathers' incomes. Unfortunately, there is no data set including both incomes for Switzerland. Instead, I use independent samples. In the sons' sample, individuals have reported certain characteristics of their fathers. The fathers' sample contains the same variables. I use these reported characteristics to predict fathers' incomes. Björklund and Jäntti (1997) have already carefully elaborated this approach. For the fathers' sample, they have access to data from a time period when the fathers were actually working. Unfortunately, this is not possible for Switzerland. To generate fathers' income I revert to a sample from a period that differs to the actual fathers' work period. However, I will point out how this biases my results. Nevertheless, this new empirical approach has two main advantages: First, as I use instruments to predict fathers' life time income, this technique does not require more than a single year for the fathers' income due to the orthogonality assumption between the instruments and the transitory fluctuations of a single year's income. Second, as I am not restricted to match a son with his actual father, I can include any observation from the sons' sample which has provided paternal characteristics. This means that I can include individuals at every age. Some studies (e.g. Grawe 2005) have shown that the measure of intergenerational income transmission is very sensitive to a son's age class. Most studies face the problem that the observed child is very young and neglect that those children with higher life-time incomes experience a higher income growth later in their lifes. The resulting measurement error of the child's life time income leads to a downward bias of the intergenerational correlation (see Solon 2002, Bound et. al. 1994). As I do not attempt to match sons with their real fathers, I can use the entire age range of the child sample. Thus, my results are not affected by such a downward bias.

This paper will proceed as follows. Section II describes the data and the necessary adjustments due to missing values as well as the correction of the standard errors due to the IV approach with two different data sets. In Section III, I address the regression to the mean 
model and the intergenerational correlation: Part A illustrates the problem of my empirical approach and works out the resulting bias of the least squares coefficient. In Part B, the results from the least squares estimations are presented. Section IV covers the differences in the intergenerational income transmission across the income distribution: Part A provides background and methods, Part B presents the results. Finally, this paper ends with a conclusion in section $\mathrm{V}$.

\section{Data and Procedures}

\section{A. Data}

The data for the sons are taken from the Swiss Household Panel (SHP) from the years 19992003. Started in 1999, the first wave of the data contains a representative sample of the Swiss population with around 5100 households and 7800 individuals. Included are only persons with a permanent residence in Switzerland. This "Living in Switzerland survey" covers a broad range of social topics and provides objective (income, living conditions, and situation within a family) as well as subjective information (attitudes, perceptions, and personal values). Further, information about the person's parents, such as fathers' education, work situation, and socio-economic position is given.

The corresponding information to calculate fathers' incomes is taken from the Swiss Labor Force Survey (SLFS), using the years 1991-2003. Based on telephone interviews, the SLFS is a rotating panel where an individual is interviewed up to five times. Besides a full range of labor information, the questionnaires also target more general socio-economic indicators.

There are three primary reasons to choose the SLFS for the fathers' sample. First, with about 17'000 households per year, the SLFS is the largest panel providing income-data for Switzerland. Second, in comparison to all other Swiss datasets, the SLFS reaches furthermost back to the year 1991. Even if the SLFS does not cover the fathers' working period, it is important to use a panel that minimizes this time distance to the period when fathers were actually working. And third, apart from the income information, the SLFS includes the same father characteristics as provided by the sons in the SHP.

I use three variables as predictors of fathers' income: the International Standard Classification of Occupations (ISCO) as a proxy for fathers' occupations, the highest education received, and a dummy indicating if the individual has Swiss citizenship. I create a set of dummies 
describing each outcome of the ISCO and education variable. ${ }^{4}$ In order to get a close correspondence between the fathers and the sons' samples, some education levels are combined. I created nine classes for the ISCO variable and eight different graduation levels. Further, I fully interacted citizenship with both education and ISCO classification. This gives me 35 different dummies to predict fathers' income.

To analyse heterogeneity by ethnicity, I define several subgroups. As there is no information about a person's origin respectively his father's origin, a son's ethnic affiliation is defined by his nationality. ${ }^{5}$ Natives are those with only a Swiss passport whose parents both have a Swiss passport only.

For completeness, as I use the sons' education later as a further control, I categorize the different education levels into three dummy variables: Those who have not completed mandatory school or who didn't pursue any other education are defined to have a low education. Those who completed vocational training or any school except advanced school have medium education. Finally, the high category contains persons who completed an advanced school allowing to enter university or who have a university degree.

I include only males aged 25 to $55 .{ }^{6}$ All sons as well as fathers have to hold a full-time or a part-time job. If they work part-time, information about the percentage of the part-time job must be given. An income from part-time work was extrapolated to a full-time job. Furthermore, I drop all those who have a work interruption longer than six months in the year of the interview. This should ensure that no earnings capacity is underestimated due to a nonearning period in the recent year. I also exclude individuals without information about fathers' socio-economic status or schooling. Finally, I drop the lowest and highest quarter percent of the income distribution. ${ }^{7}$ With 7212 observations and 2138 individuals in the sons' sample, I

\footnotetext{
${ }^{4}$ The ISCO classification is almost identical to the ISCO1- categorization (for an overview, see International Labour Office 1990). The only exception is the category of armed forces. As the Swiss Military service is a militia system, there is only a very small fraction of professional soldiers in the Swiss military system. Those are more or less in teaching functions or technicians. Therefore, I generally categorized them into the group of the technicians.

${ }^{5}$ If the son holds a Swiss citizenship, but one of his parents has a foreign nationality, the son is categorized by his parents' nationality. This is done to completely consider any ethnic impact that might result from an individual's household. Be aware that nationality is a somewhat weak variable compared to the place of birth. As a person's nationality might change, his ethnic origin - if just measured by nationality - might be unobservable. Thus, by considering parents' nationality, I can accommodate such a unobserved ethnic affiliation. Further, if both parents have different foreign nationalities, I use the father's nationality.

${ }^{6}$ The fathers sample contains men aged 25 to 65 . For robustness, I re-estimated the intergenerational correlation using only individuals aged $25-55$ in the fathers' sample. The results are very similar.

7 The SHP and the SLFS contain a few very implausible income values at the extremes of the income distribution. The exclusion of these observations should prevent a bias. For robustness, I also re-estimated the elasticities without this exlusion. The results are very similar and presented later.

410 observations were lost due to their non-working status, 46 individuals were dropped out due to a work interruption longer than six months, and 710 with no information about fathers' characteristics.
} 
keep about 85 percent of all males aged $25-55$ who filled out the personal questionnaire. ${ }^{8}$ Both for father and son, income is expressed in constant 1998 Swiss Francs using the Swiss CPI as deflator.

\section{B. Robustness checks and data adjustments}

Unfortunately, there is no information about the fathers' age given by the sons in the SHP. Thus, it is hardly possible to assign an actual working period to father. In addition, as the SLFS starts only in 1991, the data are gathered in a period that probably differs from the fathers' actual working period. Therefore, I work with several subsamples of the SLFS to test the sensitivity of my results. I compose four different father samples from the SLFS: I apply two samples from 2 waves, the first from 1991 and the wave from 1998, the year before the sons' panel has started. A further subsample includes all individuals from 1991 - 2003. For a son or father who appears in different waves, I calculate the average work income. Finally, I also generate a sample with individuals who are observed in five different waves. This is done to compare my results with a father sample that corresponds closest to a father sample usually used in the literature on intergenerational mobility. ${ }^{9}$

The summary statistics are presented in tables 1 and 2. Table 1 lists the means of the variables from the SHP for all sons and by different subsamples. Table 1 A shows the relevant sons' characteristics. Table $1 \mathrm{~B}$ presents the fathers' characteristics as reported by the sons. Table 2 shows the corresponding father characteristics in the SLFS. ${ }^{10}$ In general, the mean of the characteristics in all fathers' subsamples are similar. The sample including only individuals who are observed in 5 different years has a higher mean work income. Also, the share of fathers with an incomplete education or who only completed compulsory school is somewhat smaller than in the other subsamples. I find the strongest differences for the share of individuals with a foreign citizenship. Here, the range is between a share of $13 \%$ (for individuals observed 5 years) up to $27 \%$ (for the subsample with all individuals). ${ }^{11}$

\footnotetext{
${ }^{8}$ To evaluate the robustness of my findings, I re-estimated the model for intergenerational income mobility applying different other subgroups. The results are all similar and presented later in the text.

${ }^{9}$ A large number of studies of intergenerational mobility uses (up to) 5-years average of annual earnings (see Solon 1999, 2002).

${ }^{10}$ A number of indicators show substantially different means for the SHP and the SLFS. Thus, it is obvious that fathers' distribution in the SLFS does not correspond to the distribution in the son's sample. As a further test, I weighted the SLFS to generate an identical distribution as in the son's sample. All re-estimates are very similar to the estimates from the unweighted samples.

${ }^{11}$ Table A1 in the appendix presents the results from the prediction of fathers' incomes by subsamples of the SLFS.
} 
As the sons did not report the age of their fathers, I deduct the age component from income, both for sons and fathers: income is first regressed on a set of dummy variables for the age of the individual. The residuals combined with the intercept are then used as the age-adjusted incomes. $^{12}$

It is worth noting that the exclusion of individuals who don't work should not lead to a selection bias in this case, as the average male labour force participation rate between 1990 and 2000 in Switzerland for the age group 25 - 55 was above 97\% (BFS 2002). Thus, a correction for sample selection is not necessary. A more serious problem might result from the fact that not all individuals in the final sample provided their yearly income. In the sons' sample, there are about $14.2 \%$ missing values, in the fathers' sample $14.9 \%$. However, to maintain up the representativeness of the samples I use multiple imputation (Rubin 1978, 1987), both for the sons' as well as for the fathers' sample. ${ }^{13}$ Besides, as it is important to have an adequate number of observations in investigating different ethnic subgroups, multiple imputation augments the degrees of freedom.

Further, as I generate the father's income by a set of characteristics from a different data set, I have to adjust the standard errors. Unlike Björklund and Jäntti (1997) who estimated the asymptotic variances using a bootstrap method over both fathers' and sons' samples, I treat the fathers' income as an imputed value in the sons' data. This methodology has the advantage that it uses the calculated variances from the intergenerational transmission regression and adjusts those by the dispersion from different coefficients for each father's characteristic: I bootstrap the fathers' sample k times to generate k coefficients for each of the 35 fathers' characteristics. Thus, for each son, k different father incomes are generated (for an extended introduction to the bootstrap method, see Efron and Tibshirani 1993). The son's income is then regressed on each of the father's $\mathrm{k}$ incomes. Finally, the point estimate of the coefficient and its variance are calculated using again Rubin's $(1976,1996)$ formulas. The repeated-imputation estimate $\hat{\rho}_{\mathrm{a}}$ is the average of the k coefficients from the k regressions

\footnotetext{
${ }^{12}$ As age is a potent predictor in determining incomes, to filter out the age component strongly reduces a possible measurement error of the resulting coefficient.

${ }^{13}$ I used a software by Schafer (Schafer 1997). Based on a multivariate normal distribution, a system of simultaneous regression models is used in which each variable depends on all others (Schafer and Olsen 1998). The assumed missingness mechanism is "missing at random" (Rubin 1976, Little \& Rubin 1987). I apply a large set of dummies for age, the socio-economic status in different forms (ISCO- Index, Wright class index, Swiss socio-economic index), schooling, and the size of the company the individual is working in (in numbers of employees). For the set of the sons, I additionally included different socio-economic status of the fathers (ISCO, Wright class index, Swiss Socio-Economic Status), and their schooling. Using data augmentation (Tanner \& Wong, 1987), I replace the missing values by a set of 5 plausible values. After performing identical analysis on each of the 5 datasets, the results (estimates and standard errors) are combined, using simple rules provided by Rubin (1987).
} 


$$
\widehat{\rho}_{\mathrm{a}}=\sum_{\mathrm{q}=1}^{\mathrm{k}} \hat{\rho}_{\mathrm{q}} / \mathrm{k}
$$

The variance is

$$
\operatorname{Var}\left(\widehat{\rho}_{\mathrm{a}}\right)=\mathrm{W}+\frac{\mathrm{k}+1}{\mathrm{k}} \mathrm{B}
$$

where $\mathrm{B}$ is the between imputation variability

$$
\mathrm{B}=\sum_{\mathrm{q}=1}^{\mathrm{k}}\left(\widehat{\rho}_{\mathrm{q}}-\widehat{\rho}_{\mathrm{a}}\right)^{2} /(\mathrm{k}-1)
$$

and $\mathrm{W}$ is the within-imputation variability

$$
\mathrm{W}=\sum_{\mathrm{q}=1}^{\mathrm{k}} \operatorname{Var}\left(\hat{\rho}_{\mathrm{q}}\right) / \mathrm{k}
$$

Thus, the adjusted variance (2) is composed of an averaged variance from the son-father regression in the sons' sample (within-variance $\mathrm{W}$ ) and the dispersion in the different $\hat{\rho}_{\mathrm{q}}$ 's resulting from differences in the bootstrapped incomes of the fathers (between-variance B), i.e. the adaptation of the variance from the estimated coefficients in the fathers' sample.

\section{Intergenerational Correlation}

\section{A. Bias and measurement error of the least squares coefficient}

Following the classical approach, I define the son's long-run income as a function of the father's long-run income

$$
\mathrm{y}_{\mathrm{si}}=\rho \mathrm{y}_{\mathrm{fi}}+\varepsilon_{\mathrm{i}}
$$

where both $\mathrm{y}_{\mathrm{si}}$ and $\mathrm{y}_{\mathrm{fi}}$ are $\log$ incomes and measured as deviations from their respective means; $\varepsilon_{\mathrm{i}}$ is white noise. Now, there are three main measurement problems I am confronted with when analysing the intergenerational income mobility in Switzerland. The first and probably best known in the literature of intergenerational mobility is the non-observability of life-time income. Solon (1992) has shown that using annual income as a proxy for long-run income yields a downwards inconsistency of the least squares estimate $\rho$. Assuming that the son's and the father's annual income $\mathrm{y}_{\text {sit }}$ and $\mathrm{y}_{\mathrm{fit}}$ are defined as

$$
\mathrm{y}_{\text {sit }}=\mathrm{y}_{\mathrm{si}}+\mathrm{v}_{\text {sit }}
$$

and 


$$
\mathrm{y}_{\text {fit }}=\mathrm{y}_{\mathrm{fi}}+\mathrm{v}_{\mathrm{fit}},
$$

yearly earnings are assumed to equal long-run earnings plus a transitory fluctuation, $\mathrm{v}_{\text {sit }}$ for the sons and $\mathrm{v}_{\text {fit }}$ for the fathers, respectively. As the variance of the fathers' transitory fluctuation appears in the denominator of the least squares estimator, the true parameter is underestimated. Solon (1992) has pointed out that if annual income is available for several years, the inconsistency can be reduced:

$$
\overline{\mathrm{y}}_{\mathrm{fi}}=\frac{1}{\mathrm{~T}} \sum_{\mathrm{t}=1}^{\mathrm{T}}\left(\mathrm{y}_{\mathrm{fi}}+\mathrm{v}_{\mathrm{fit}}\right)=\mathrm{y}_{\mathrm{fi}}+\overline{\mathrm{v}}_{\mathrm{fi}}
$$

The higher the number of yearly incomes $\mathrm{T}$ that approximate the life-time income, the less $\operatorname{Var}\left(\bar{v}_{\mathrm{fi}}\right)$, and the less underestimated is the resulting income correlation.

The second problem results from the non-availability of the fathers' yearly earnings. As I have no data on the fathers' annual incomes, but observe only some characteristics of the fathers, I assume that $\mathrm{y}_{\mathrm{fi}}$ is described by the following equation

$$
\mathrm{y}_{\mathrm{fi}}=\beta^{\prime} \mathrm{X}_{\mathrm{fi}}+\mathrm{u}_{\mathrm{fi}} \text {. }
$$

where the variance of $y_{\mathrm{fi}}$, the fathers' life-time income, is

$$
\operatorname{Var}\left(\mathrm{y}_{\mathrm{fi}}\right)=\beta^{\prime} \mathrm{X}_{\mathrm{fi}} \mathrm{X}_{\mathrm{fi}}^{\prime} \beta+\sigma_{\mathrm{u}_{\mathrm{fi}}}^{2}
$$

$\mathrm{X}_{\mathrm{fi}}$ is a vector of explanatory variables, $\beta$ is a coefficient vector and $\mathrm{u}_{\mathrm{fi}}$ the stochastic term that can not be explained by the characteristics $X_{\mathrm{fi}}$. If $\mathrm{X}_{\mathrm{fi}}$ completely explains the fathers' life-time income, $\mathrm{u}_{\mathrm{fi}}$ would be zero. Following Björklund and Jäntti (1993), the resulting estimate of $\rho$ has the following probability limit:

$$
\lim _{\mathrm{N}_{\mathrm{s}} \rightarrow \infty} \hat{\rho}=\frac{\operatorname{Cov}\left(\mathrm{y}_{\mathrm{si}}, \mathrm{y}_{\mathrm{fi}}\right)-\operatorname{Cov}\left(\mathrm{y}_{\mathrm{si}} \mathrm{u}_{\mathrm{fi}}\right)}{\beta^{\prime} X_{\mathrm{fi}} X_{\mathrm{fi}}^{\prime} \beta}
$$

Compared to the unbiased least squares estimator of $\rho$, the numerator of equation $(11)^{14}$ will be reduced by the covariance between the sons life-time income and $\mathrm{u}_{\mathrm{fi}}$. The denominator will be reduced as the variance of the predicted father's income $\hat{\beta}^{\prime} X_{\mathrm{fi}}$ does not include $\sigma_{\mathrm{u}_{\mathrm{fi}}}$. Björklund and Jäntti (1997) have provided one example where expression (11) overestimates the true $\rho .^{15}$

\footnotetext{
${ }^{14}$ For a complete derivation of equation (7), see Björklund and Jäntti (1993).

15 They have compared income mobility in Sweden and the United States. While the Swedish data lacks actual fathers' income, the U.S. sample both contains the sons' as well as their fathers' incomes. Thus, a comparison between equation (1) and equation (7) could be provided for the U.S.
} 
The third problem when analysing intergenerational income transmission in Switzerland is new in the mobility literature. I can not use a fathers' sample from the correct period, i.e. when fathers were really working. Instead, I use a sample from a period that probably differs from the fathers' actual work period. Fortunately, I can in large parts adopt the empirical procedure by Björklund and Jäntti (1993) and reintegrate this further problem. ${ }^{16}$ My point of departure is again equation (9). Substituting equation (8) for $\mathrm{y}_{\mathrm{fi}}$ into (9) yields

$$
\bar{y}_{\mathrm{fi}}=\beta^{\prime} \mathrm{X}_{\mathrm{fi}}+\mathrm{u}_{\mathrm{fi}}+\overline{\mathrm{v}}_{\mathrm{fi}}
$$

$\beta$ describes the correlation between the fathers' characteristics and their incomes. As the sample period does not correspond to the fathers' working period, I can not estimate $\beta$ properly. Instead, my estimation is

$$
\bar{y}_{\mathrm{fi}}=(\beta+\gamma)^{\prime} \mathrm{X}_{\mathrm{fi}}+\mathrm{u}_{\mathrm{fi}}+\overline{\mathrm{v}}_{\mathrm{fi}}
$$

where $\beta$ is the real correlation between the fathers' characteristics and the fathers' income at the time when the fathers were actually working, and $\gamma$ is the change in time of this correlation from the real working period up to the time when the fathers are observable.

Using least squares, my estimated $\widehat{\beta}$ for calculating the fathers' income has now the following equation

$$
\begin{aligned}
& \widehat{\beta}=\left(X^{\prime} X\right)^{-1} X^{\prime} \bar{y}=\left(X^{\prime} X\right)^{-1} X^{\prime} X \beta+\left(X^{\prime} X\right)^{-1} X^{\prime} X \gamma_{t}+\left(X^{\prime} X\right)^{-1} X^{\prime} u+\left(X^{\prime} X\right)^{-1} X^{\prime} \bar{v} \\
& =\beta+\gamma+\left(X^{\prime} X\right)^{-1} X^{\prime} u+\left(X^{\prime} X\right)^{-1} X^{\prime} \bar{v}
\end{aligned}
$$

As the number of observations in the fathers' sample $N_{f}$ is large, then $\lim _{N_{f} \rightarrow \infty}\left(X^{\prime} X\right)^{-1} X^{\prime} u \rightarrow 0$ and $\lim _{N_{f} \rightarrow \infty}\left(X^{\prime} X\right)^{-1} X^{\prime} \bar{v} \rightarrow 0$, and $\widehat{\beta}$ corresponds to $\beta$ and $\gamma \cdot{ }^{17}$ The fathers' long-run income can be calculated inserting the coefficients $\widehat{\beta}$, estimated in the fathers' sample, into the sons' sample

$$
\widehat{y}_{\mathrm{fi}}=\widehat{\beta}^{\prime} X_{\mathrm{fi}}^{\mathrm{s}}=\beta^{\prime} X_{\mathrm{fi}}^{\mathrm{s}}+\gamma^{\prime} X_{\mathrm{fi}}^{\mathrm{s}}+\left(\left(X^{\prime} X\right)^{-1} X^{\prime} \mathrm{u}\right)^{\prime} X_{\mathrm{fi}}^{\mathrm{s}}+\left(\left(X^{\prime} X\right)^{-1} X^{\prime} \bar{v}\right)^{\prime} X_{\mathrm{fi}}^{\mathrm{s}}
$$

$\mathrm{X}_{\mathrm{fi}}^{\mathrm{s}}$ is a matrix containing the fathers' characteristics, reported by the sons.

Defining $U=\left(\left(X^{\prime} X\right)^{-1} X^{\prime} u\right)^{\prime} X_{f i}^{s}, \bar{V}=\left(\left(X^{\prime} X\right)^{-1} X^{\prime} \bar{v}\right)^{\prime} X_{f i}^{s}$, and $\Delta y_{f i}=\gamma^{\prime} X_{f i}^{s}$, and substituting equation (9) into (15) yields

$$
\widehat{y}_{\mathrm{fi}}=\mathrm{y}_{\mathrm{fi}}+\Delta \mathrm{y}_{\mathrm{fi}}+\mathrm{U}+\overline{\mathrm{V}}-\mathrm{u}_{\mathrm{fi}}
$$

And due to the orthogonality assumption

\footnotetext{
${ }^{16}$ For convenience, I use a similar notation they used.

17 This follows from orthogonality between the stochastic terms $u_{\mathrm{fi}}$ and $\bar{v}$ and the fathers' characteristics. For a detailed analysis of the properties of the estimates from IV regression from two samples, see Angrist and Krueger (1992).
} 


$$
\widehat{\mathrm{y}}_{\mathrm{fi}}=\mathrm{y}_{\mathrm{fi}}+\Delta \mathrm{y}_{\mathrm{fi}}-\mathrm{u}_{\mathrm{fi}}
$$

The true fathers' income and the estimated fathers' income differ in two ways: First, unlike $\mathrm{y}_{\mathrm{fi}}, \widehat{\mathrm{y}}_{\mathrm{fi}}$ contains $\Delta \mathrm{y}_{\mathrm{fi}}$, the change of the father's income due to a change of the correlation in time between the father's characteristics and the father's long-run income. Also, as the father's characteristics do not cover the complete life-time income, $\hat{\mathrm{y}}_{\mathrm{fi}}$ does not include $u_{\mathrm{fi}}$, the stochastic component of $\mathrm{y}_{\mathrm{fi}}$. The estimation of $\rho$ has now the following probability limit

$$
\begin{aligned}
& \lim _{\mathrm{N}_{\mathrm{s}} \rightarrow \infty} \hat{\rho}=\lim _{\mathrm{N}_{\mathrm{s}} \rightarrow \infty} \frac{\sum_{\mathrm{i}=1}^{\mathrm{N}} \mathrm{y}_{\mathrm{si}}^{\prime} \widehat{\mathrm{y}}_{\mathrm{fi}} / \mathrm{N}_{\mathrm{s}}}{\sum_{\mathrm{i}=1}^{\mathrm{N}} \widehat{\mathrm{y}}_{\mathrm{fi}}^{2} / \mathrm{N}_{\mathrm{s}}} \\
& =\lim _{\mathrm{N}_{\mathrm{s}} \rightarrow \infty} \frac{\sum_{\mathrm{i}=1}^{\mathrm{N}} \mathrm{y}_{\mathrm{si}}^{\prime}\left(\mathrm{y}_{\mathrm{fi}}+\Delta \mathrm{y}_{\mathrm{fi}}-\mathrm{u}_{\mathrm{fi}}\right)}{\beta_{\mathrm{fi}}^{\mathrm{s}} \mathrm{X}_{\mathrm{fi}}^{\mathrm{s}} \beta+\gamma^{\prime} \mathrm{X}_{\mathrm{fi}}^{\mathrm{s}} \mathrm{X}_{\mathrm{fi}}^{\mathrm{s}} \gamma+2 \beta^{\prime} \mathrm{X}_{\mathrm{fi}}^{\mathrm{s}} \mathrm{X}_{\mathrm{fi}}^{\mathrm{s}}{ }^{\prime} \gamma} \\
& =\frac{\operatorname{Cov}\left(\mathrm{y}_{\mathrm{si}} \mathrm{y}_{\mathrm{fi}}\right)+\operatorname{Cov}\left(\mathrm{y}_{\mathrm{si}} \Delta \mathrm{y}_{\mathrm{fi}}\right)-\operatorname{Cov}\left(\mathrm{y}_{\mathrm{si}} \mathrm{u}_{\mathrm{fi}}\right)}{\beta^{\prime} \mathrm{X}_{\mathrm{fi}}^{\mathrm{s}} \mathrm{X}_{\mathrm{fi}}^{\mathrm{s}}{ }^{\prime} \beta+\operatorname{Var}\left(\Delta \mathrm{y}_{\mathrm{fi}}\right)+2 \operatorname{Cov}\left(\mathrm{y}_{\mathrm{fi}}, \Delta \mathrm{y}_{\mathrm{fi}}\right)}
\end{aligned}
$$

It is recognizable that equation (18) contains the same terms as equation (11), the resulting estimator from Björklund and Jäntti (1993). Further, the bias in equation (18) depends on the variance of $\Delta \mathrm{y}_{\mathrm{fi}}$, the change of the fathers' income, and its covariance with the son's and the father's life-time income. In case that fathers' income would not have changed over time, i.e. $\gamma_{\mathrm{t}}=0$, equation (18) and equation (11) would be identical and my results could be directly compared to the results by Björklund and Jäntti (1997). Of course, such an assumption is not plausible. But it would be much less restrictive to assume that the change in the fathers' long run income is independent of the sons' and fathers' long run income, i.e. that the covariances are both zero. Keep in mind that $\Delta \mathrm{y}_{\mathrm{fi}}$ is the difference between the real and the observed fathers' income. This difference results from a change of the correlations between certain income predicting characteristics and income. There might be several reasons why such relationships between theses characteristic and income might have changed, for example due to a progress in technology or a change in the supply or demand of a certain profession. But there is no reason to expect that the fathers' real income should be related to this (chronologically later) change in time of the influence of the fathers' characteristics on the incomes.

However, given this assumption, equation (18) can be simplified to

$$
\lim _{\mathrm{N}_{\mathrm{s}} \rightarrow \infty} \widehat{\rho}=\frac{\operatorname{Cov}\left(\mathrm{y}_{\mathrm{si}}, \mathrm{y}_{\mathrm{fi}}\right)-\operatorname{Cov}\left(\mathrm{y}_{\mathrm{si}} \mathrm{u}_{\mathrm{fi}}\right)}{\beta^{\prime} X_{\mathrm{fi}}^{\mathrm{s}} X_{\mathrm{fi}}^{\mathrm{s}}{ }^{\prime} \beta+\operatorname{Var}\left(\Delta y_{\mathrm{fi}}\right)}
$$


or

$$
\lim _{\mathrm{s}_{\mathrm{s}} \rightarrow \infty} \hat{\rho}==\underbrace{\left(1-\frac{\operatorname{Cov}\left(\mathrm{y}_{\mathrm{si}} \mathrm{u}_{\mathrm{fi}}\right)}{\operatorname{Cov}\left(\mathrm{y}_{\mathrm{si}} \mathrm{y}_{\mathrm{fi}}\right)}\right)}_{=\mathrm{A}} * \underbrace{\frac{\beta^{\prime} X_{\mathrm{fi}}^{\mathrm{s}} \mathrm{X}_{\mathrm{fi}}^{\mathrm{s}} \beta+\sigma_{\mathrm{u}_{\mathrm{fi}}}^{2}}{\beta^{\prime} X_{\mathrm{fi}}^{\mathrm{s}} X_{\mathrm{fi}}^{\mathrm{s}}{ }^{\prime} \beta+\sigma_{\Delta \mathrm{y}_{\mathrm{fi}}}^{2}} \rho}_{=\mathrm{B}}
$$

where $\sigma_{\mathrm{u}_{\mathrm{fi}}}^{2}$ and $\sigma_{\Delta \mathrm{y}_{\mathrm{fi}}}^{2}$ are the variances of $\mathrm{u}_{\mathrm{fi}}$ and $\Delta \mathrm{y}_{\mathrm{fi}}$ respectively.

Unfortunately, we can hardly see in which direction the estimator in equation (20) is biased compared to the unbiased $\rho$. If $\operatorname{Cov}\left(\mathrm{y}_{\mathrm{si}}, \mathrm{u}_{\mathrm{fi}}\right)$ and $\operatorname{Cov}\left(\mathrm{y}_{\mathrm{si}}, \mathrm{y}_{\mathrm{fi}}\right)$ have the same sign, $\mathrm{A}$ is less than 1. On the other side, $\mathrm{B}$ is less than 1 if $\sigma_{\Delta \mathrm{yf}_{\mathrm{fi}}}^{2}>\sigma_{\mathrm{u}_{\mathrm{fi}}}^{2}$. The better the fathers' life-time incomes can be explained by their characteristics, the smaller will be $u_{\mathrm{fi}}$ and $\sigma_{\mathrm{u}_{\mathrm{fi}}}^{2}$. At the extreme, in case that their characteristics would completely explain the variance of fathers' income, $\sigma_{u_{\mathrm{f}}}^{2}$ would be zero, B would be less than 1 and the estimated parameter would be downward biased. ${ }^{18}$

However, another interesting point is that equation (19) only differs from equation (11) in the variance of $\Delta y_{f i}$ in the denominator. Thus, my resulting estimator is downward biased compared to the estimator of Björklund and Jäntti (1993): Their results can be regarded as a lower bound. This means that although the direction of the resulting bias is not detectable, cross-national comparison might still be possible. For example, if I would find higher elasticities for Switzerland compared to the elasticities they found for the U.S. and Sweden, a conclusion that mobility is lower in Switzerland would be appropriate.

\section{B. Results from the least squares estimation}

I start presenting the estimated elasticities using OLS. Table 3 A shows the least squares coefficients for different subsamples of the SLFS. Focusing first on the SLFS wave from 1991 , I find an overall elasticity of $0.455 .{ }^{19}$ With an elasticity of 0.55 compared to 0.38 , the estimates for immigrants are much higher than those for the natives. If I compare sons having an immigrant father to sons being immigrants, the elasticity even rises up to 0.62 . Generally, it seems that immigrants are more likely to tread in their fathers' footsteps regarding their income than natives. Analysing the group of immigrants in greater detail, there are strong differences between ethnic groups. I find the highest elasticity for Spain, Portugal, and Italy. The smallest coefficients are found for Germany and South Eastern Europe, which are not

\footnotetext{
18 At another extreme, in case that $\operatorname{Cov}\left(\mathrm{y}_{\mathrm{si}}, \mathrm{u}_{\mathrm{fi}}\right)=\operatorname{Cov}\left(\mathrm{y}_{\mathrm{si}}, \mathrm{y}_{\mathrm{fi}}\right)$, the estimated coefficient would be zero.

${ }^{19}$ Under the assumption mentioned in the section above, Switzerland is less mobile than Sweden. As the corresponding value for the U.S. lies above the Swiss elasticity, inference is not possible.
} 
even significant. It is of interest that those ethnicities with high elasticities have a similar migration background: immigrants from Italy and Spain typically entered in the 1950s and 1960s during an economic boom period in Switzerland. Mostly, they worked in blue collar jobs. In contrast, the migrational inflow from immigrants from South Eastern Europe came in the 1980s and - as a consequence of the civil war in Former Yugoslavia - in the 1990s. Their migration motives are much more heterogeneous than those of the Spanish and the Italians. Besides the small number of observations, this might be a reason why there is no significant relationship between sons' and fathers' incomes for South Eastern Europe.

Column 3 shows the intergenerational elasticity with a control for the sons' education. The inclusion of education in the estimation allows one to measure how much of the intergenerational income correlation is due to educational attainment. The stronger the reduction of the elasticity the more powerful is education in explaining the intergenerational transmission. Further, it is of interest to analyse whether education has a different impact on the intergenerational income mobility by ethnicity. Generally, there is an overall reduction of the mobility-coefficient by about $40 \%$. This finding is in line with the previous research. (e.g. Eide and Showalter 1999, Blanden $2005^{20}$ ). The reduction is somewhat higher for immigrants than for the Swiss. Education seems to be more important if one has a father with a foreign nationality. The reduction is about $49 \%$ compared to $39 \%$ for individuals with a Swiss father. Conditional on a son's nationality, as a simple interpretation, education is most valuable for Spanish and Portuguese whereas their mean level of education is also lowest. On the other hand, education only accounts for roughly 18 percent for French immigrants whereas their mean level of education is highest. Generally, differences in the impact of education on the intergenerational income mobility simply seem to reflect differences in the level of education across different ethnic groups.

For robustness, columns $4-6$ of table $3 \mathrm{~A}$ show the correspondent results for different compositions of the fathers' sample. The data section has already addressed the importance of such robustness checks. Analysing all individuals, the coefficients for the other subsamples lie between 0.41 and 0.44. On average, using the fathers' sample from the year 1991 leads to larger elasticities of about $0.03-0.04$ compared to the sample from 1998; the sample including all fathers from 1991 to 2003 undervalues the results by about 0.03 compared to wave 1991. For the subsample with fathers who appear in five different waves, the elasticity is somewhat smaller than that of the 1991. It is hard to say if these smaller values result due to

\footnotetext{
${ }^{20}$ Blanden (2005) has decomposed the elasticity for the U.S., UK and West Germany. She finds that education explain between 35 and 50 percent of the intergenerational mobility. In contrast, recent studies from Aydemir et. al. (2006) only find a weak impact of education on the intergenerational elasticity for Canadian immigrants.
} 
a worse correspondence of the respective fathers' sample to the real fathers' sample. However, the numbers in brackets in columns $4-6$ indicate t-values for the null hypothesis that the parameters in column $4-6$ are identical to the corresponding ones in column $2 .^{21}$ With a single exception ${ }^{22}$, this hypothesis can not be rejected for all subsamples even of a 10 percent level of significance. Thus, the results are not sensitive regarding a specific subsample of the fathers.

For another check of the sensitivity of my results, table $3 \mathrm{~B}$ presents the least squares estimates using different subsamples of the SHP. I concentrate on the fathers' sample from wave $1991 .^{23}$ Column 1 presents again the results as in column 1 of table 3 A. Columns 2 to 4 test the robustness of the coefficient regarding the included observations. This is an important point as most other studies dealing with intergenerational mobility do not restrict the data in the manner I do. The resulting elasticities are somewhat smaller, but still similar. The deviation of the results is 0.03 at most. This indicates that a different subsample from the SHP does not result in a vastly different interpretation of the intergenerational relation between father and son.

Finally, table $3 \mathrm{C}$ shows the different elasticities by age groups of the sons. Similar to the conclusion of Bound et. al. (1994), the younger the included sons, the stronger intergenerational mobility is biased downwards. Note that table $3 \mathrm{C}$ presents the measures with both age-adjusted incomes for the fathers and for the sons. Even this correction cannot avoid the large measurement error.

\section{Measuring differences across the income distribution}

\section{A. Background and methods}

Using least squares, the elasticity measures the linear correlation between a son's economic status and that of his father's. This measure is important since it describes a society's mobility

\footnotetext{
${ }^{21}$ The t-values are calculated using standard bootstrap method (Efron and Tibshirani 1993).

22 The fathers' subsample including all individuals from 1991 to 2003 significantly differs on a 10 percent level to the fathers' subsample 1991 if all sons are included. However, on a 5 percent level, the null hypothesis that parameters are identical can not be rejected.

${ }^{23}$ There are three reasons to do so: First, all results seem to be very robust concerning the different subsamples of fathers. Thus, no further information would derive from the presentation of all estimations from the other subsamples. Second, for the 1991 wave, the timely distance between the father's real and observable work period is (probably) minimal. Third, the distribution of the father's characteristics from the SLFS in 1991 mostly corresponds - measured as the total deviation in absolute terms - to the distribution of the characteristics, reported in the SHP.
} 
as a whole. However, recent studies also concentrate on the question whether parental inheritance varies with the son's (or father's) position in the income distribution. Even if two societies have the same least squares elasticity, they might differ in their equality of opportunity as one society may discriminate individuals of a certain income quantile more than the other. For example, imagine a society where the average persistence of income is very low, but this averaged elasticity is compounded of a very mobile upper class and a very immobile lower class. Of course, such a society provides equality of opportunity on average, but unfortunately, this equality of opportunity depends on parental background. This indicates that a single elasticity measure might neglect substantial differences in the intergenerational transmission within a society. Besides the least squares estimation, it is therefore important to investigate nonlinearities regarding certain income quantiles. Becker and Tomes (1986) have provided a theoretical base for the assumption that there might be differences in the intergenerational mobility across income quantiles. Assuming imperfection of capital markets, their theory predicts that those families who suffer the most from capital market restrictions will experience the least intergenerational mobility because an appropriate investment in the child's future might not be possible. Becker and Tomes (1986) proposed that low income families are mostly affected by credit constraints because their investment in the child's human capital mostly relies on financial borrowing. Therefore, intergenerational mobility should be lower at the bottom of the income distribution. However, the question of who suffers most from such a capital market imperfection is discussed controversially. Han and Mulligan (2001) have argued that children from low-earning families are typically less able and therefore less constrained as they need fewer investments. High ability children tend to come from high-earnings families. Thus, the earnings elasticity should be higher at the top of the earnings distribution. However, Corak and Heisz (1999) have argued that even if highly able children originate from well earning families, those should have the financial capacities to be independent of credit constraints. They conclude that middle-earning families tend to be most sensitive to credit constraints as they have more able children and a stronger dependence on capital markets (for an overview see Grawe and Mulligan 2002).

Other empirical results are mixed: Eide and Showalter (1999), Bratberg, Nilsen and Vaage (2005), and Mazumder (2001) confirm Becker and Tomes' hypothesis; Corak and Heisz (1999) and Behrman and Taubman (1990) show the opposite.

I present two different measures to investigate transmission patterns across the income distribution in Switzerland. First, I consider descriptive statistics of the intergenerational income transmission matrices for different subsamples. Then, I apply quantile regression to 
estimate different elasticitites conditional on the explanatory variables. As described by Koenker and Bassett (1978) or Buchinsky (1998), the model is specified as

$$
\widehat{\beta}_{\theta}=\min \sum_{\mathrm{y}_{\mathrm{si}} \geq \mathrm{y}_{\mathrm{fi}}^{\prime} \beta_{\theta}}\left|\mathrm{y}_{\mathrm{si}}-\mathrm{y}_{\mathrm{fi}}^{\prime} \beta_{\theta}\right| \theta+\sum_{\mathrm{y}_{\mathrm{si}}<\mathrm{x}_{\mathrm{f}}^{\prime} \beta_{\theta}}\left|\mathrm{y}_{\mathrm{si}}-\mathrm{y}_{\mathrm{fi}}^{\prime} \beta_{\theta}\right|(1-\theta) .
$$

Here, $\theta$ indicates a specific quantile. Quantile regression allows one to explore intergenerational transmission at different points of the income distribution. It is therefore a useful tool to test whether a son-father income relation is independent of the position in the son's income distribution. As the function is not differentiable at the origin, equation (21) can be solved using linear programming. A simplex algorithm derived by Armstrong et al. (1979) is used.

\section{B. Results of the quantile analysis}

Table 4 first provides the descriptive statistics of the intergenerational income transmission matrices for all, and separately for natives and immigrants and individuals having a native or immigrant father respectively. ${ }^{24}$ Again, I only present the results from the SLFS 1991. With respect to a father's income quartile, each number indicates a son's probability to attain a certain income quartile. Table 4 A shows the transition matrix for all individuals. The overall immobility index - measured by adding values found in the principal diagonal and adjacent cells - for Switzerland is 3.01. This value lies in between the immobility index for the U.S. with 3.08 and West Germany with 2.92 calculated by Blanden (2005). ${ }^{25}$ Tables 4 B and C present the probabilities for natives and for immigrants separately. Generally, there is a tendency for a stronger intergenerational persistence among immigrants compared to the Swiss. Given that his father is also in the lowest quartile, a son's probability for staying in the lowest quartile is $44.4 \%$ for immigrants and $37.5 \%$ for Swiss. On the other side, given a father from the highest quartile, an immigrant's probability to belong to the highest quartile is $41 \%$. The equivalent probability for the Swiss is $37 \%$. Considering the sons with respect to their father's citizenship (table $4 \mathrm{D}$ and E), I find that about 39\% of all individuals who descend from an immigrant father from the lowest income quantile are in the lowest quartile. Contrarily, if the father has Swiss citizenship, the probability is about $36 \%$. However, almost $48 \%$ of individuals with an immigrant fathers from the highest quartile are also high earners. The number for individuals with a Swiss father is somewhat lower. Here, the probability is

\footnotetext{
${ }^{24}$ Table 4 presents the descriptive statistics without the imputed values for missing sons' income.

25 Blanden (2005) compared intergenerational mobility for the UK, the United States, West Germany and Canada, also using a quartile transition matrix. The correspondent immobility index for the UK is 2.885 and 2.771 for Canada.
} 
about $37 \%$. Compared to the Swiss with a value of 2.92 , the aggregate index of immobility for immigrants reaches about 3.19 .

Table $4 \mathrm{~F}$ summarizes the ratios of a son's probability to be in the highest quartile to the probability to be in the lowest quartile conditional on the father's income position. Having a father in the lowest income quartile, this ratio is lower for immigrants than for natives. This indicates that the upward mobility for the Swiss is higher than that for the immigrants. However, I find higher ratios for the immigrants if the father belongs to the highest income quartile. Column 6 of table $4 \mathrm{E}$ directly compares the different ratios between natives and immigrants. Column 7 shows the difference between individuals with a Swiss father to an individual with an immigrant father. Immigrants both have a significant lower upward probability, but also a significant lower downward probability than natives.

Table 5 presents the results from the quantile regressions. The dependent variable is the sons' averaged log income from the period 1999 - 2003. The fathers' income is taken from the year $1991 .^{26}$ The overall picture in column 1 is that the estimated coefficients are similar for all quantiles of the sons' income distribution. ${ }^{27}$ There is a small rise at the upper end of the income distribution that indicates that the intergenerational mobility is somewhat lower for high earners. The range of the estimated coefficient lies between 0.42 for the $7^{\text {th }}$ percentile and 0.52 for the $9^{\text {th }}$ percentile. Starting at the $10^{\text {th }}$ percentile, the father - son relation rises somewhat up to 0.5 to the third percentile and then declines to the $7^{\text {th }}$ when it starts rising again to 0.52 .

To ease the interpretation, figures 1 A - D illustrate the results graphically. I distinguish between Swiss and immigrants as well as Swiss father and immigrant father respectively. Each subsample is estimated separately. Immigrants in every income quantile have a higher elasticity than the corresponding natives. I find a somewhat opposite pattern for natives and immigrants. For natives, the highest elasticity is found for sons located in the highest part of income distribution. The lowest part is found at the $75^{\text {th }}$ quantile. For immigrants, the lowest elasticity is found for sons from the lowest percentile. Conversely, the highest father-son relation is found at the $75^{\text {th }}$ quantile. The graph of sons with a native father runs somewhat flatly. This indicates that parental inheritance is similar for all income quantiles. For individuals with an immigrant father, the elasticity declines at the tails of the income distribution. Fathers' income is most important for the sons' income at the third quartile. Generally, while the curve for the Swiss is flat, the corresponding curve for the immigrants

\footnotetext{
${ }^{26}$ See section II for an explanation of the calculation of the standard errors.

${ }^{27}$ The results for the 5th and the 95th quantiles are not presented here. As the fathers' incomes correspond to a mean income for a specific set of characteristics, it can not be guaranteed that the pattern at the very end of the distribution does not result due to measurement errors.
} 
indicates a variation in the importance of the fathers' income to the sons' income among different quantiles. I find strongest differences for sons with an immigrant father. ${ }^{28}$

Finally, Table 6 shows the reduction of the intergenerational coefficients due to the inclusion of education as a control in the quantile regression. The educational impact is strongest for those quantiles with the highest elasticities. While the natives have a mean reduction of the coefficients of about $37 \%$, the average decrease for immigrants is $43 \%$ and $46 \%$ for individuals with an immigrant father.

How can we interpret these results for Switzerland? As discussed in section V, differences in the intergenerational mobility across quantiles of the income distribution might be explained by the credit constraints hypothesis (Becker and Tomes 1986): the intergenerational transmission will be higher for those who suffer more from capital market constraints and therefore for those who cannot invest in their children adequately. Regarding the Swiss, fathers' incomes are equally important for all sons' income quantiles. Hence with a mean elasticity of 0.39 , Switzerland seems to provide equality of opportunity equally across the income distribution, at least for the natives. Focusing on education as a strong indicator for a child's human capital, these similar intergenerational coefficients across different quantiles for Switzerland might become quite explainable. In contrast to other countries - e.g. the United States - education is publicly financed and Switzerland provides a public schooling system that enjoys a very high reputation. The public school is generally preferred to private institutions, even by the upper class. A good education is not dependant on parental financial effort. This also holds true for tertiary education. All Swiss universities have low and stable tuition fees. ${ }^{29}$ Thus, the Swiss schooling system assists in particular low earning families who cannot afford to invest in their child's education. This might be the reason why I do not find a similar pattern as Eide and Showalter (1999) for the U.S. and Bratberg et. al. (2005) for Norway. They all found a stronger intergenerational income correlation for sons at the bottom of the income distribution.

It remains the question why there are some differences in the intergenerational mobility across the income distribution for the immigrants and for individuals with an immigrant father. Besides a mean elasticity of about 0.59 indicating that they suffer from a significantly higher intergenerational persistence compared to the Swiss, there is also strong heterogeneity

\footnotetext{
28 Table A2 and figures A1 A - D in the appendix present the quantile regression with a control for education. Again, I distinguish between Swiss and immigrants as well as individuals with a Swiss and an immigrant father respectively. Almost all differences in the sons' income quantile have disappeared. Thus, education is a very powerful factor in reducing heterogeneity in the intergenerational income transmission across the income distribution.

${ }^{29}$ The average tuition is 1400 CHF per year without any other costs. Children with parents under a certain income level will be financially assisted by the government, regardless of their schooling performance.
} 
across different quantiles of immigrants. Probably, these differences first of all reflect heterogeneity among different ethnic groups. However, an additional explanation could be that a certain number of these immigrants do not have appropriate human capital investment due to a different schooling system in their country of origin. This can be accentuated if education is a stronger signal to evaluate immigrants than natives as other factors like behavior, adaptability or mentality of immigrants might by unknown or at least misunderstood in the host country. Thus, those who are able to send the (host country's) right signal will be preferred to those who are not able to do that. This might explain why some non-natives have obviously less equality of opportunity than others. Nevertheless, as I find highest intergenerational mobility at the lower end of the income distribution among immigrants, Switzerland seems to provide equality of opportunity for low earners among immigrants.

\section{Conclusion}

The number of countries for which the intergenerational income and earnings transmission has been investigated in the literature is still small. This paper tries contribute to this literature by delivering results for Switzerland, a country that has not been analysed yet regarding income mobility.

But, what can we learn from this study? As described in section III, due to methodological differences to other papers, a comparison with other countries must be drawn very cautiously. If some weak assumptions hold, the presented coefficients can be compared to the results presented by Björklund and Jäntti (1993) which can be regarded as a lower bound. In that case, intergenerational income mobility is lower for Switzerland compared to Sweden. However, using descriptive quartile transition matrices, the Swiss immobility index indicating a country's degree of immobility - can be compared to results from Blanden (2005) who analysed intergenerational mobility for four different countries. The Swiss value lies between the corresponding indices for West Germany and the U.S. which is the higher one (whereas the UK and Canada both have smaller values than Switzerland). Thus, although this study can only shed some light on a cross- national comparison, Switzerland tends not to belong to those countries that provide high levels of equality of opportunity.

A within-country comparison across subgroups of the Swiss population shows strong differences between Swiss and immigrants. With an intergenerational income elasticity of 
0.55 , immigrants tend to be substantially more immobile than Swiss with an elasticity of 0.38 . Also, substantial heterogeneity is found among different ethnic groups. The son-father relation is strongest for immigrants from Spain, Portugal, and Italy which have typically been countries of origin of blue collar guest workers in Switzerland. The smallest elasticity is found for those from Germany and South East Europe. Controlled for education, there is an overall reduction of the mobility-coefficient by about $40 \%$. Generally, the impact of education on the intergenerational transmission seems to be negatively related to the level of education of a specific ethnic group. Thus, heterogeneity in the income mobility among ethnicities can in large parts be eliminated by an appropriate educational investment.

Analysing differences across the income distribution, immigrants have a significantly lower upward as well as downward mobility than natives. Intergenerational income elasticities conditional on the sons' income quantile are similar for natives across the income distribution. There are somewhat higher elasticities at the lower as well as at the higher end. In contrast, an opposite structure is found for immigrants. Here, mobility is higher at the tails of the income distribution whereas highest elasticity is found for sons in the 75 th quantile. These patterns for Switzerland are in conflict with previous results from other countries who either find highest mobility among high-earning or low-earning families. Also, the conclusion from previous studies (e.g. Eide and Showalter 1999) that education is more valuable at the bottom of the earnings distribution can not be supported in this study. Education seems simply to be the mechanism to reduce heterogeneity in intergenerational mobility across the income distribution and its impact is not conditional on a certain income quantile.

\section{References}

Angrist, Joshua D. and Krueger, Alan D. (1992) The Effect on Age at School Entry on Educational Attainment: An Application of Instrumental Variables with Moments from Two Samples. Journal of the American Statistical Association 87, 328-336

Armstrong, Ronald D., Frome, E.L. and Kung, D.S. (1979) A revised simplex algorithm for the absolute deviation curve fitting problem. Comm. Statist. - Simula. Computa. B8 (2), 175 - 190

Aydemir, Abdurrahman, Chen, Wen-Hao and Corak, Miles (2006) Intergenerational Earnings Mobility among Children of Canadian Immigrants. IZA DP No. 2085

Bauer, Philipp and Riphahn, Regina T. (2005) Heterogeneity in the Intergenerational Transmission of Educational Attainment: Evidence from Switzerland on Natives and Second Generation Immigrants. Journal of Population Economics, forthcoming

Bauer, Philipp and Riphahn, Regina T. (2006) Education and its intergenerational transmission: Evidence for natives and immigrants from Switzerland, mimeo 
Becker, Gary S. and Tomes, Nigel (1986) Human Capital and the Rise and Fall of Families. Journal of Labor Economics 4 (3, Part 2), 1 - 39

Behrman, Jere R. and Taubman, Paul (1990) The Intergenerational correlation between children's adult earnings and their parents' income: results from the Michigan panel survey of income dynamics. Review of Income and Wealth 36 (2), 115 - 127

BFS (Bundesamt für Statistik) (2002) Arbeit und Erwerb: Deutliche Zunahme der Erwerbsbevölkerung. Pressemitteilung, Juni

BFS (Bundesamt für Statistik) (2005) Statistisches Jahrbuch der Schweiz 2004. Verlag Neue Züricher Zeitung, Zürich

Björklund, Anders and Jäntti, Markus (1993) Intergenerational Income Mobility in Sweden Compared to the United States. Working paper, Instiutet för Social Forskning

Björklund, Anders and Jäntti, Markus (1997) Intergenerational Income Mobility in Sweden Compared to the United States. American Economic Review 87 (5), 1009-1018

Blanden, Jo (2005) International Evidence on Intergenerational Mobility. London School of Economics, Centre for Economic Performance, Unpublished paper.

Borjas, George J. (1993) The Intergenerational Mobility of Immigrants. Journal of Labor Economics 11 (1, Part 1), 113 - 135

Bound, John, Brown, Charles, Duncan, Greg J and Rodgers, Willard L. (1994) Evidence on the Validity of Cross-sectional and Longitudinal Labor Market Data. Journal of Labor Economics 12 (3), $345-68$.

Bratberg, Espen, Nielsen, Oivind A. and Vaage, Kjell (2005) Intergenerational Mobility: Trends Across the Earnings Distribution. IZA DP No. 1517

Buchinsky, Moshe (1998) Recent Advances in Quantile Regression Models: A Practical Guideline for Empirical Research. The Journal of Human Resource 33 (1), 88 - 126

Corak, Miles and Heisz, Andrew (1999) The intergenerational Earnings and Income Mobility of Canadian Men: Evidence from Longitudinal Income Tax Data. Journal of Human Resources 34 (3), $504-533$

Efron, Bradley and Tibshirani, Robert J. (1993) An Introduction to the Bootstrap. Chapman and Hall, New York

Eide, Eric R, and Showalter, Mark H (1999) Factors Affecting the Transmission of Earnings Across Generations: A Quantile Regression Approach. The Journal of Human Resources 34 (2), 253 - 267

Erikson, Robert and Goldthorpe, John H. (2002) Intergenerational Inequality: A Sociological Perspective. Journal of Economic Perspectives 16 (3), 31 - 44

Grawe, Nathan D. and Mulligan, Casey B. (2002) Economic Interpretations of Intergenerational Correlations. The Journal of Economic Perspectives 16 (3), 45 - 58

Grawe, Nathan D. (2005) Lifecycle bias in estimates of intergenerational earnings persistence. Labour Economic, forthcoming 
Hammarstedt, Mats and Palme, Mårten (2006) Intergenerational Mobility, Human Capital Transmission and the Earnings of Second-Generation Immigrants in Sweden. IZA DP No. 1943

Han, Song and Mulligan; Casey B. (2001) Human Capital, Heterogeneity, and Estimated Degrees of Intergenerational Mobility. Economic Journal 111 (4), 207 - 43

Haug, Werner (2002) The Demography of Immigrant Populations in Europe. European Population Papers Series No. 8

International Labour Office (1990) ISCO-88 International Standard Classification of Occupations, Genf: ILO

Koenker, Roger and Bassett Jr, Gilbert (1978) Regression Quantiles. Econometrica 46 (1), 33-50.

Little, Roderick J and Rubin, Donald B. (1987) Statistical analysis with missing data. J. Wiley \& Sons, New York

Mazumder, Bhashkar (2001) Earnings Mobility in the US: A New Look at Intergenerational Inequality. Federal Reserve Bank of Chicago, Working Paper 2001-18

OECD (2002) Education at a Glance. OECD Indicators 2002, OECD, Paris.

Rubin, Donald B. (1976) Inference and missing data. Biometrika, 63, 581 - 592

Rubin, Donald B. (1978) Multiple Imputation in Sample Surveys - A Phenomenological Bayesian Approach to Nonresponse. Proceedings of the Survey Research Methods Sections of the American Statistical Association, 20 - 34

Rubin, Donald B. (1987) Multiple Imputation for Nonresponse in Surveys. J. Wiley \& Sons, New York.

Rubin, Donald B. (1996) Multiple Imputation After 18+ Years. Journal of the American Statistical Association 91, 473-489

Schafer, Joseph L. (1997) Analysis of Incomplete Multivariate Data. Chapman \& Hall; London

Schafer, J.L. and Olsen, M.K. (1998) Multiple imputation for multivariate missing-data problems: a data analyst's perspective. Multivariate Behavioral Research 33, 545-571

Solon, Gary M. (1992) Intergenerational income mobility in the United States. American Economic Review 82, $393-408$

Solon, Gary M. (1999) Intergenerational Mobility in the Labor Market. in: Ashenfelter, O. and Card, D.: Handbook of Labor Economics 3 A, 1761 - 1800

Solon, Gary M. (2002) Cross-country differences in intergenerational earnings mobility. Journal of Economic Perspectives 16 (3), 59-66.

Tanner, Martin, and Wong, Wing Hung (1987) The calculation of posterior distributions by data augmentation. Journal of the American Statistical Association 82, 528 - 540

Zahner Rossler, Claudia (2005) PISA 2003: Kompetenzen für die Zukunft, Zweiter nationaler Bericht. Bundesamt für Statistik (BFS), Neuchâtel 
Table 1 A Descriptive statistics on sons' characteristics in the sons' sample (SHP) by subsample

\begin{tabular}{|c|c|c|c|c|c|c|c|c|c|c|}
\hline Variable & $\begin{array}{c}\text { All } \\
\text { mean } \\
\text { (std. dev.) }\end{array}$ & $\begin{array}{c}\text { Natives } \\
\text { mean } \\
\text { (std. dev.) }\end{array}$ & $\begin{array}{c}\text { Immigrants } \\
\text { mean } \\
\text { (std. dev.) }\end{array}$ & $\begin{array}{l}\text { Native father } \\
\text { mean } \\
\text { (std. dev.) }\end{array}$ & $\begin{array}{c}\text { Immigrant father } \\
\text { mean } \\
\text { (std. dev.) }\end{array}$ & $\begin{array}{l}\text { S.E. Europe } \\
\text { mean } \\
\text { (std. dev.) }\end{array}$ & $\begin{array}{c}\text { Italy } \\
\text { mean } \\
\text { (std. dev.) }\end{array}$ & $\begin{array}{c}\text { Germany } \\
\text { mean } \\
\text { (std. dev.) }\end{array}$ & $\begin{array}{c}\text { France } \\
\text { mean } \\
\text { (std. dev.) }\end{array}$ & $\begin{array}{c}\text { Spain / Portugal } \\
\text { mean } \\
\text { (std. dev.) } \\
\end{array}$ \\
\hline Son's yearly work income & $\begin{array}{c}80575 \\
(40486)\end{array}$ & $\begin{array}{c}82323 \\
(40127)\end{array}$ & $\begin{array}{c}76751 \\
(41037)\end{array}$ & $\begin{array}{c}82340 \\
(40211)\end{array}$ & $\begin{array}{c}74710 \\
(40890)\end{array}$ & $\begin{array}{c}50487 \\
(15520)\end{array}$ & $\begin{array}{l}71200 \\
(26750)\end{array}$ & $\begin{array}{c}82367 \\
(43545)\end{array}$ & $\begin{array}{l}89897 \\
(57487)\end{array}$ & $\begin{array}{c}60081 \\
(32544)\end{array}$ \\
\hline Age adjusted log income & $\begin{array}{c}10.855 \\
(0.38)\end{array}$ & $\begin{array}{l}10.874 \\
(0.373)\end{array}$ & $\begin{array}{l}10.814 \\
(0.392)\end{array}$ & $\begin{array}{l}10.879 \\
(0.372)\end{array}$ & $\begin{array}{l}10.777 \\
(0.396)\end{array}$ & $\begin{array}{l}10.522 \\
(0.236)\end{array}$ & $\begin{array}{c}10.774 \\
(0.32)\end{array}$ & $\begin{array}{l}10.887 \\
(0.393)\end{array}$ & $\begin{array}{l}10.914 \\
(0.464)\end{array}$ & $\begin{array}{l}10.649 \\
(0.418)\end{array}$ \\
\hline Son's age & $\begin{array}{c}40.652 \\
(8.57)\end{array}$ & $\begin{array}{l}41.147 \\
(8.708)\end{array}$ & $\begin{array}{c}39.584 \\
(8.17)\end{array}$ & $\begin{array}{l}40.995 \\
(8.658)\end{array}$ & $\begin{array}{l}39.526 \\
(8.184)\end{array}$ & $\begin{array}{l}37.104 \\
(6.439)\end{array}$ & $\begin{array}{c}40.049 \\
(8.53)\end{array}$ & $\begin{array}{l}39.867 \\
(7.222)\end{array}$ & $\begin{array}{l}40.605 \\
(8.686)\end{array}$ & $\begin{array}{l}36.882 \\
(7.391)\end{array}$ \\
\hline Son's education: low (0/1) (ref.) & $\begin{array}{c}0.059 \\
(0.236)\end{array}$ & $\begin{array}{c}0.034 \\
(0.182)\end{array}$ & $\begin{array}{c}0.114 \\
(0.318)\end{array}$ & $\begin{array}{c}0.034 \\
(0.182)\end{array}$ & $\begin{array}{c}0.142 \\
(0.349)\end{array}$ & $\begin{array}{c}0.167 \\
(0.377)\end{array}$ & $\begin{array}{c}0.168 \\
(0.375)\end{array}$ & $\begin{array}{c}0.018 \\
(0.132)\end{array}$ & $\begin{array}{c}0.053 \\
(0.225)\end{array}$ & $\begin{array}{c}0.333 \\
(0.476)\end{array}$ \\
\hline Son's education: middle (0/1) & $\begin{array}{c}0.698 \\
(0.459)\end{array}$ & $\begin{array}{l}0.755 \\
(0.43)\end{array}$ & $\begin{array}{c}0.577 \\
(0.494)\end{array}$ & $\begin{array}{c}0.745 \\
(0.436)\end{array}$ & $\begin{array}{c}0.546 \\
(0.498)\end{array}$ & $\begin{array}{c}0.625 \\
(0.489)\end{array}$ & $\begin{array}{c}0.664 \\
(0.473)\end{array}$ & $\begin{array}{c}0.558 \\
(0.499)\end{array}$ & $\begin{array}{c}0.487 \\
(0.503)\end{array}$ & $\begin{array}{c}0.51 \\
(0.505)\end{array}$ \\
\hline Son's education: high (0/1) & $\begin{array}{c}0.242 \\
(0.429)\end{array}$ & $\begin{array}{c}0.211 \\
(0.408)\end{array}$ & $\begin{array}{c}0.31 \\
(0.463)\end{array}$ & $\begin{array}{c}0.221 \\
(0.415)\end{array}$ & $\begin{array}{c}0.312 \\
(0.464)\end{array}$ & $\begin{array}{l}0.208 \\
(0.41)\end{array}$ & $\begin{array}{c}0.168 \\
(0.375)\end{array}$ & $\begin{array}{c}0.425 \\
(0.497)\end{array}$ & $\begin{array}{c}0.461 \\
(0.502)\end{array}$ & $\begin{array}{c}0.157 \\
(0.367)\end{array}$ \\
\hline Share of subsample by ethnic group & $100.00 \%$ & $68.29 \%$ & $31.71 \%$ & $76.61 \%$ & $23.39 \%$ & $2.25 \%$ & $10.57 \%$ & $5.29 \%$ & $3.55 \%$ & $2.39 \%$ \\
\hline $\begin{array}{l}\text { No. obs. } \\
\text { No. obs.: income item nonresponse }\end{array}$ & $\begin{array}{c}2138 \\
318\end{array}$ & $\begin{array}{c}1460 \\
211\end{array}$ & $\begin{array}{l}678 \\
107\end{array}$ & $\begin{array}{c}1638 \\
239\end{array}$ & $\begin{array}{c}500 \\
79\end{array}$ & $\begin{array}{c}48 \\
7\end{array}$ & $\begin{array}{c}226 \\
42\end{array}$ & $\begin{array}{c}113 \\
15\end{array}$ & $\begin{array}{l}76 \\
14\end{array}$ & $\begin{array}{c}51 \\
7\end{array}$ \\
\hline
\end{tabular}

Note: Description from the SHP 1999 - 2003 before multiple imputation. Standard errors are in parentheses. Individuals were grouped by their nationality and the parents' nationality respectively.

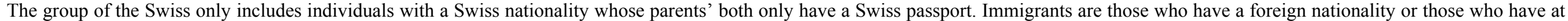
least one parent with a foreign nationality. South Eastern Europe contains immigrants from former Yugoslavia, Turkey, and Greece. 
Table 1 B Descriptive statistics on fathers' income predictors in the sons' sample (SHP) by subsample

\begin{tabular}{|c|c|c|c|c|c|c|c|c|c|c|}
\hline Variable & $\begin{array}{l}\text { All } \\
\text { mean } \\
\text { (std. } \\
\text { dev.) } \\
\end{array}$ & $\begin{array}{l}\text { Natives } \\
\text { mean } \\
\text { (std. } \\
\text { dev.) } \\
\end{array}$ & $\begin{array}{l}\text { Immigrants } \\
\text { mean } \\
\text { (std. dev.) }\end{array}$ & $\begin{array}{c}\text { Native } \\
\text { father } \\
\text { mean }\end{array}$ & $\begin{array}{l}\text { Immigrant } \\
\text { father } \\
\text { mean }\end{array}$ & $\begin{array}{l}\text { S.E. Europe } \\
\text { mean } \\
\text { (std. dev.) }\end{array}$ & $\begin{array}{c}\text { Italy } \\
\text { mean } \\
\text { (std. dev.) }\end{array}$ & $\begin{array}{l}\text { Germany } \\
\text { mean } \\
\text { (std. dev.) }\end{array}$ & $\begin{array}{l}\text { France } \\
\text { mean } \\
\text { (std. dev.) }\end{array}$ & $\begin{array}{l}\text { Spain / } \\
\text { Portugal } \\
\text { mean } \\
\text { (std. dev.) }\end{array}$ \\
\hline
\end{tabular}

\section{Father's ISCO classification}

Legislators, senior officials, managers (0/1)

$\begin{array}{cccccccccc}0.074 & 0.07 & 0.083 & 0.072 & 0.08 & 0.042 & 0.035 & 0.115 & 0.145 & 0.02 \\ (0.262) & (0.255) & (0.275) & (0.259) & (0.272) & (0.202) & (0.185) & (0.32) & (0.354) & (0.14) \\ 0.108 & 0.101 & 0.122 & 0.107 & 0.112 & 0.042 & 0.027 & 0.159 & 0.197 & 0.059 \\ (0.311) & (0.302) & (0.328) & (0.309) & (0.316) & (0.202) & (0.161) & (0.368) & (0.401) & (0.238) \\ 0.17 & 0.182 & 0.146 & 0.181 & 0.134 & 0.104 & 0.093 & 0.195 & 0.197 & 0.039 \\ (0.376) & (0.386) & (0.353) & (0.385) & (0.341) & (0.309) & (0.291) & (0.398) & (0.401) & (0.196) \\ 0.073 & 0.073 & 0.074 & 0.076 & 0.064 & - & 0.058 & 0.142 & 0.079 & 0.078 \\ (0.26) & (0.26) & (0.262) & (0.265) & (0.245) & - & (0.233) & (0.35) & (0.271) & (0.272) \\ 0.03 & 0.025 & 0.041 & 0.027 & 0.038 & 0.042 & 0.044 & 0.018 & 0.066 & 0.059 \\ (0.17) & (0.155) & (0.199) & (0.164) & (0.191) & (0.202) & (0.206) & (0.132) & (0.25) & (0.238) \\ 0.136 & 0.162 & 0.081 & 0.15 & 0.09 & 0.167 & 0.106 & 0.035 & 0.026 & 0.137 \\ (0.343) & (0.368) & (0.273) & (0.357) & (0.286) & (0.377) & (0.309) & (0.186) & (0.161) & (0.348) \\ 0.259 & 0.245 & 0.288 & 0.247 & 0.298 & 0.313 & 0.358 & 0.274 & 0.263 & 0.353 \\ (0.438) & (0.43) & (0.453) & (0.431) & (0.458) & (0.468) & (0.481) & (0.448) & (0.443) & (0.483) \\ 0.072 & 0.078 & 0.059 & 0.074 & 0.064 & 0.083 & 0.097 & 0.035 & 0.013 & 0.059 \\ (0.259) & (0.268) & (0.236) & (0.263) & (0.245) & (0.279) & (0.297) & (0.186) & (0.115) & (0.238) \\ 0.078 & 0.065 & 0.106 & 0.065 & 0.12 & 0.208 & 0.181 & 0.027 & 0.013 & 0.196 \\ (0.268) & (0.247) & (0.308) & (0.247) & (0.325) & (0.41) & (0.386) & (0.161) & (0.115) & (0.401)\end{array}$

\section{Father's education}

Incompleted and completed compulsory school (0/1) (ref.)

Elementary vocational training (0/1)

$\begin{array}{ccccccccccc}0.226 & 0.187 & 0.31 & 0.185 & 0.36 & 0.458 & 0.491 & 0.097 & 0.132 & 0.627 \\ (0.418) & (0.39) & (0.463) & (0.388) & (0.48) & (0.504) & (0.501) & (0.298) & (0.34) & (0.488) \\ 0.052 & 0.046 & 0.066 & 0.045 & 0.078 & 0.167 & 0.111 & 0.009 & 0.013 & 0.039 \\ (0.223) & (0.209) & (0.249) & (0.206) & (0.268) & (0.377) & (0.314) & (0.094) & (0.115) & (0.196) \\ 0.011 & 0.015 & 0.003 & 0.014 & 0.002 & - & 0.004 & - & - & - & - \\ (0.105) & (0.122) & (0.054) & (0.118) & (0.045) & - & (0.067) & - & - & & - \\ & & & & & & & & & & \\ 2138 & 1460 & 678 & 1638 & 500 & 48 & 226 & 113 & 76 & 51\end{array}$

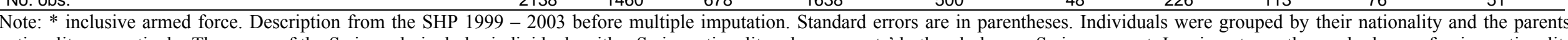

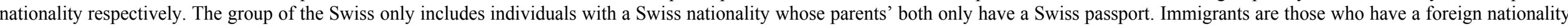
or those who have at least one parent with a foreign nationality. South Eastern Europe contains immigrants from former Yugoslavia, Turkey, and Greece. 
Table 1 B (continued)

\begin{tabular}{|c|c|c|c|c|c|c|c|c|c|c|}
\hline Variable & $\begin{array}{c}\text { All } \\
\text { mean } \\
\text { (std. dev.) }\end{array}$ & $\begin{array}{c}\text { Natives } \\
\text { mean } \\
\text { (std. dev.) }\end{array}$ & $\begin{array}{l}\text { Immigrants } \\
\text { mean } \\
\text { (std. dev.) }\end{array}$ & $\begin{array}{l}\text { Native father } \\
\text { mean } \\
\text { (std. dev.) }\end{array}$ & $\begin{array}{l}\text { Immigrant } \\
\text { father } \\
\text { mean } \\
\text { (std. dev.) }\end{array}$ & $\begin{array}{l}\text { S.E. Europe } \\
\text { mean } \\
\text { (std. dev.) }\end{array}$ & $\begin{array}{c}\text { Italy } \\
\text { mean } \\
\text { (std. dev.) }\end{array}$ & $\begin{array}{l}\text { Germany } \\
\text { mean } \\
\text { (std. dev.) }\end{array}$ & $\begin{array}{c}\text { France } \\
\text { mean } \\
\text { (std. dev.) }\end{array}$ & $\begin{array}{c}\text { Spain / } \\
\text { Portugal } \\
\text { mean } \\
\text { (std. dev.) }\end{array}$ \\
\hline
\end{tabular}

Father's education (continued)

Apprenticeship (0/1)

2 to 3 years: full time vocational school (0/1)

$\begin{array}{ccccc}0.43 & 0.483 & 0.317 & 0.48 & 0.268 \\ (0.495) & (0.5) & (0.466) & (0.5) & (0.443) \\ 0.028 & 0.028 & 0.027 & 0.03 & 0.02 \\ (0.164) & (0.165) & (0.161) & (0.17) & (0.14) \\ 0.035 & 0.033 & 0.04 & 0.032 & 0.044 \\ (0.184) & (0.178) & (0.196) & (0.177) & (0.205) \\ 0.13 & 0.14 & 0.108 & 0.137 & 0.106 \\ (0.336) & (0.348) & (0.31) & (0.344) & (0.308) \\ 0.087 & 0.068 & 0.13 & 0.077 & 0.122 \\ (0.283) & (0.252) & (0.336) & (0.267) & (0.328)\end{array}$

0.25
$(0.438)$

Maturity or teacher's Training college (0/1)

Fed certif, technical school (0/1)

University (0/1)

0.234

No swiss citizenship (0/1)

$(0.423)$

(1)

(0.328)

-

0.021

(0.144)

0.042

0.042
$(0.202)$

0.063

(0.245)

0.27
$(0.445)$
0.035

0.469

(0.501)

$\begin{array}{cc}(0.185) & (0.132) \\ 0.009 & 0.062\end{array}$

$(0.094)-(0.242)$

$(0.094)$

0.058
$(0.233)$

$(0.242)$
0.168

(0.376)

(0.147)

0.177

(0.383)

0.368

$(0.486)$

0.176

0.039

0.02

$(0.196)$
0.079

0.02

$(0.271)$

0.211

(0.41)

0.158

(0.367)

$(0.238)$

0.078

(0.272)

\section{Father's age adjusted log income}

Fathers observed at least 5 years

\begin{tabular}{lcccccccccc}
10.834 & 10.846 & 10.808 & 10.853 & 10.771 & 10.675 & 10.687 & 10.913 & 10.926 & 10.678 \\
$(0.233)$ & $(0.231)$ & $(0.234)$ & $(0.231)$ & $(0.226)$ & $(0.188)$ & $(0.171)$ & $(0.204)$ & $(0.217)$ & $(0.205)$ \\
10.777 & 10.784 & 10.76 & 10.792 & 10.728 & 10.63 & 10.634 & 10.868 & 10.882 & 10.62 \\
$(0.248)$ & $(0.247)$ & $(0.25)$ & $(0.247)$ & $(0.243)$ & $(0.202)$ & $(0.18)$ & $(0.223)$ & $(0.232)$ & $(0.218)$ \\
10.845 & 10.864 & 10.806 & 10.87 & 10.763 & 10.677 & 10.694 & 10.909 & 10.92 & 10.671 \\
$(0.226)$ & $(0.222)$ & $(0.228)$ & $(0.223)$ & $(0.217)$ & $(0.182)$ & $(0.174)$ & $(0.187)$ & $(0.209)$ & $(0.211)$ \\
10.772 & 10.78 & 10.755 & 10.788 & 10.722 & 10.627 & 10.631 & 10.861 & 10.872 & 10.619 \\
$(0.238)$ & $(0.237)$ & $(0.239)$ & $(0.238)$ & $(0.231)$ & $(0.195)$ & $(0.175)$ & $(0.209)$ & $(0.22)$ & $(0.21)$ \\
& & & & & & & & & & \\
2138 & 1460 & 678 & 1638 & 500 & 48 & 226 & 113 & 76 & 51 \\
\hline
\end{tabular}

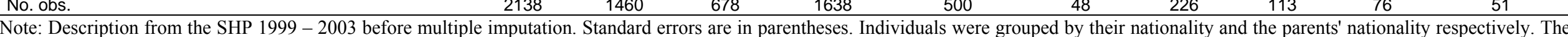

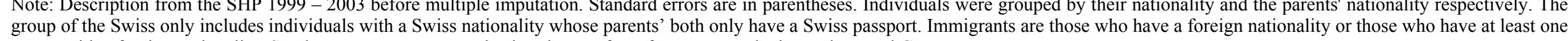
parent with a foreign nationality. South Eastern Europe contains immigrants from former Yugoslavia, Turkey, and Greece. 
Table 2 Descriptive statistics on father's income predictors in the father's sample (SLFS) by subsample

\begin{tabular}{|c|c|c|c|c|}
\hline Variable & $\begin{array}{c}\text { Individuals } \\
\text { observed } 5 \\
\text { years }\end{array}$ & $\begin{array}{c}\text { All individuals } \\
\text { Sample } 1991 \text { - } \\
2003\end{array}$ & $\begin{array}{c}\text { Sample } \\
1991\end{array}$ & $\begin{array}{c}\text { Sample } \\
1998\end{array}$ \\
\hline Father's yearly real work income & $\begin{array}{c}80536 \\
(39660)\end{array}$ & $\begin{array}{c}77168 \\
(44160)\end{array}$ & $\begin{array}{c}77054 \\
(41156)\end{array}$ & $\begin{array}{c}76386 \\
(38190)\end{array}$ \\
\hline Father's age & $\begin{array}{l}41.888 \\
(9.475)\end{array}$ & $\begin{array}{c}42.245 \\
(10.694)\end{array}$ & $\begin{array}{c}41.032 \\
(10.906)\end{array}$ & $\begin{array}{c}41.614 \\
(10.404)\end{array}$ \\
\hline Mean wave year of father's observation & $\begin{array}{c}1997 \\
(2.974)\end{array}$ & $\begin{array}{c}1999 \\
(4.192)\end{array}$ & $\begin{array}{c}1991 \\
(0)\end{array}$ & $\begin{array}{c}1998 \\
(0)\end{array}$ \\
\hline Father's ISCO classification & & & & \\
\hline Legislators, senior officials, managers $(0 / 1)$ & $\begin{array}{c}0.094 \\
(0.291)\end{array}$ & $\begin{array}{c}0.089 \\
(0.285)\end{array}$ & $\begin{array}{c}0.059 \\
(0.236)\end{array}$ & $\begin{array}{c}0.102 \\
(0.302)\end{array}$ \\
\hline Professionals (0/1) & $\begin{array}{c}0.216 \\
(0.411)\end{array}$ & $\begin{array}{c}0.2 \\
(0.4)\end{array}$ & $\begin{array}{l}0.187 \\
(0.39)\end{array}$ & $\begin{array}{c}0.204 \\
(0.403)\end{array}$ \\
\hline Technicians and associate professionals* $(0 / 1)$ & $\begin{array}{c}0.203 \\
(0.403)\end{array}$ & $\begin{array}{c}0.182 \\
(0.386)\end{array}$ & $\begin{array}{c}0.2 \\
(0.4)\end{array}$ & $\begin{array}{c}0.202 \\
(0.402)\end{array}$ \\
\hline Clercs (0/1) & $\begin{array}{c}0.077 \\
(0.266)\end{array}$ & $\begin{array}{c}0.08 \\
(0.271)\end{array}$ & $\begin{array}{c}0.111 \\
(0.314)\end{array}$ & $\begin{array}{c}0.072 \\
(0.258)\end{array}$ \\
\hline Service workers, market sales workers $(0 / 1)$ & $\begin{array}{c}0.056 \\
(0.229)\end{array}$ & $\begin{array}{l}0.067 \\
(0.25)\end{array}$ & $\begin{array}{c}0.056 \\
(0.229)\end{array}$ & $\begin{array}{c}0.066 \\
(0.248)\end{array}$ \\
\hline Skilled agricultural and fishery workers (0/1) & $\begin{array}{l}0.046 \\
(0.21)\end{array}$ & $\begin{array}{c}0.04 \\
(0.195)\end{array}$ & $\begin{array}{c}0.037 \\
(0.188)\end{array}$ & $\begin{array}{c}0.047 \\
(0.211)\end{array}$ \\
\hline Craft and related trades workers $(0 / 1)$ & $\begin{array}{c}0.207 \\
(0.405)\end{array}$ & $\begin{array}{c}0.223 \\
(0.417)\end{array}$ & $\begin{array}{c}0.22 \\
(0.414)\end{array}$ & $\begin{array}{c}0.203 \\
(0.403)\end{array}$ \\
\hline Plant and machine operater assemblers (0/1) & $\begin{array}{c}0.074 \\
(0.261)\end{array}$ & $\begin{array}{c}0.081 \\
(0.273)\end{array}$ & $\begin{array}{c}0.081 \\
(0.272)\end{array}$ & $\begin{array}{c}0.071 \\
(0.257)\end{array}$ \\
\hline Elementary occupations (0/1) (ref.) & $\begin{array}{c}0.028 \\
(0.165)\end{array}$ & $\begin{array}{c}0.038 \\
(0.191)\end{array}$ & $\begin{array}{c}0.05 \\
(0.217)\end{array}$ & $\begin{array}{l}0.033 \\
(0.18)\end{array}$ \\
\hline Father's education & & & & \\
\hline incompleted and completed compulsory school (0/1) (ref.) & $\begin{array}{c}0.064 \\
(0.245)\end{array}$ & $\begin{array}{l}0.108 \\
(0.31)\end{array}$ & $\begin{array}{c}0.08 \\
(0.271)\end{array}$ & $\begin{array}{c}0.075 \\
(0.263)\end{array}$ \\
\hline Elementary vocational training $(0 / 1)$ & $\begin{array}{c}0.016 \\
(0.127)\end{array}$ & $\begin{array}{c}0.023 \\
(0.151)\end{array}$ & $\begin{array}{c}0.039 \\
(0.194)\end{array}$ & $\begin{array}{c}0.014 \\
(0.117)\end{array}$ \\
\hline School of commerce $(0 / 1)$ & $\begin{array}{c}0.019 \\
(0.135)\end{array}$ & $\begin{array}{c}0.017 \\
(0.128)\end{array}$ & $\begin{array}{c}0.021 \\
(0.145)\end{array}$ & $\begin{array}{c}0.008 \\
(0.091)\end{array}$ \\
\hline Apprenticeship (0/1) & $\begin{array}{c}0.446 \\
(0.497)\end{array}$ & $\begin{array}{c}0.418 \\
(0.493)\end{array}$ & $\begin{array}{c}0.449 \\
(0.497)\end{array}$ & $\begin{array}{c}0.459 \\
(0.498)\end{array}$ \\
\hline 2 to 3 years: full time vocational school $(0 / 1)$ & $\begin{array}{c}0.044 \\
(0.205)\end{array}$ & $\begin{array}{c}0.054 \\
(0.225)\end{array}$ & $\begin{array}{l}0.056 \\
(0.23)\end{array}$ & $\begin{array}{l}0.051 \\
(0.22)\end{array}$ \\
\hline Maturity or teacher's Training college $(0 / 1)$ & $\begin{array}{c}0.047 \\
(0.211)\end{array}$ & $\begin{array}{c}0.052 \\
(0.222)\end{array}$ & $\begin{array}{c}0.046 \\
(0.209)\end{array}$ & $\begin{array}{c}0.048 \\
(0.214)\end{array}$ \\
\hline Fed certif, technical school (0/1) & $\begin{array}{c}0.239 \\
(0.427)\end{array}$ & $\begin{array}{c}0.193 \\
(0.395)\end{array}$ & $\begin{array}{c}0.197 \\
(0.398)\end{array}$ & $\begin{array}{c}0.224 \\
(0.417)\end{array}$ \\
\hline University (0/1) & $\begin{array}{c}0.125 \\
(0.331)\end{array}$ & $\begin{array}{c}0.135 \\
(0.342)\end{array}$ & $\begin{array}{c}0.112 \\
(0.315)\end{array}$ & $\begin{array}{c}0.122 \\
(0.327)\end{array}$ \\
\hline Father's assimilation & & & & \\
\hline No swiss citizenship (0/1) & $\begin{array}{c}0.13 \\
(0.336)\end{array}$ & $\begin{array}{c}0.274 \\
(0.446)\end{array}$ & $\begin{array}{c}0.202 \\
(0.401)\end{array}$ & $\begin{array}{c}0.144 \\
(0.351)\end{array}$ \\
\hline $\begin{array}{l}\text { No. obs. } \\
\text { No. obs.: income item nonresponse }\end{array}$ & $\begin{array}{c}25630 \\
3124\end{array}$ & $\begin{array}{c}41362 \\
6739\end{array}$ & $\begin{array}{l}4608 \\
1049\end{array}$ & $\begin{array}{c}4828 \\
634\end{array}$ \\
\hline
\end{tabular}

Note: * inclusive armed forces. Description from SLFS before multiple imputation. Standard errors are in parentheses. Fathers yearly real work income not age adjusted 
Table 3 A Least squares estimation of $\rho$ by subsamples of the SLFS - Elasticities

\begin{tabular}{|c|c|c|c|c|c|c|}
\hline & no. obs. & $\begin{array}{c}\text { Fathers } \\
1991\end{array}$ & $\begin{array}{c}\text { Fathers } \\
1991 \\
\text { controlled for } \\
\text { sons' education } \\
\text { (3) }\end{array}$ & $\begin{array}{c}\text { Fathers } \\
1998\end{array}$ & $\begin{array}{l}\text { All fathers } \\
1991-2003\end{array}$ & $\begin{array}{c}\text { Fathers } \\
\text { observed } \\
\text { at least } 5 \text { years }\end{array}$ \\
\hline All & 2138 & $\begin{array}{c}0.455 \\
(0.041)\end{array}$ & $\begin{array}{c}0.276 \\
(0.039)\end{array}$ & $\begin{array}{c}0.405 \\
(0.041) \\
{[1.060]}\end{array}$ & $\begin{array}{c}0.411 \\
(0.034) \\
{[1.362]}\end{array}$ & $\begin{array}{c}0.442 \\
(0.036) \\
{[0.463]}\end{array}$ \\
\hline Swiss & 1460 & $\begin{array}{c}0.382 \\
(0.048)\end{array}$ & $\begin{array}{c}0.231 \\
(0.046)\end{array}$ & $\begin{array}{c}0.334 \\
(0.046) \\
{[0.747]}\end{array}$ & $\begin{array}{c}0.348 \\
(0.04) \\
{[0.870]}\end{array}$ & $\begin{array}{c}0.372 \\
(0.042) \\
{[0.257]}\end{array}$ \\
\hline Immigrants & 678 & $\begin{array}{c}0.551 \\
(0.064)\end{array}$ & $\begin{array}{c}0.312 \\
(0.064)\end{array}$ & $\begin{array}{c}0.518 \\
(0.063) \\
{[0.475]}\end{array}$ & $\begin{array}{c}0.507 \\
(0.055) \\
{[0.989]}\end{array}$ & $\begin{array}{c}0.546 \\
(0.058) \\
{[0.346]}\end{array}$ \\
\hline S. E. Europe & 39 & $\begin{array}{c}0.219 \\
(0.166)\end{array}$ & $\begin{array}{c}0.124 \\
(0.173)\end{array}$ & $\begin{array}{c}0.161 \\
(0.154) \\
{[0.109]}\end{array}$ & $\begin{array}{c}0.22 \\
(0.151) \\
{[0.123]}\end{array}$ & $\begin{array}{c}0.253 \\
(0.165) \\
{[0.155]}\end{array}$ \\
\hline Italy & 226 & $\begin{array}{c}0.508 \\
(0.115)\end{array}$ & $\begin{array}{l}0.297 \\
(0.11)\end{array}$ & $\begin{array}{c}0.477 \\
(0.114) \\
{[0.076]}\end{array}$ & $\begin{array}{c}0.495 \\
(0.108) \\
{[0.330]}\end{array}$ & $\begin{array}{c}0.535 \\
(0.115) \\
{[0.073]}\end{array}$ \\
\hline Germany & 113 & $\begin{array}{c}0.186 \\
(0.164)\end{array}$ & $\begin{array}{c}0.113 \\
(0.168)\end{array}$ & $\begin{array}{c}0.211 \\
(0.154) \\
{[0.073]}\end{array}$ & $\begin{array}{c}0.196 \\
(0.14) \\
{[0.055]}\end{array}$ & $\begin{array}{c}0.214 \\
(0.152) \\
{[0.029]}\end{array}$ \\
\hline France & 76 & $\begin{array}{c}0.376 \\
(0.187)\end{array}$ & $\begin{array}{c}0.309 \\
(0.186)\end{array}$ & $\begin{array}{c}0.382 \\
(0.177) \\
{[0.035]}\end{array}$ & $\begin{array}{c}0.352 \\
(0.168) \\
{[0.186]}\end{array}$ & $\begin{array}{c}0.366 \\
(0.178) \\
{[0.133]}\end{array}$ \\
\hline Spain / Portugal & 51 & $\begin{array}{c}0.631 \\
(0.178)\end{array}$ & $\begin{array}{c}0.296 \\
(0.211)\end{array}$ & $\begin{array}{c}0.591 \\
(0.177) \\
{[0.005]}\end{array}$ & $\begin{array}{c}0.611 \\
(0.17) \\
{[0.027]}\end{array}$ & $\begin{array}{c}0.671 \\
(0.178) \\
{[0.153]}\end{array}$ \\
\hline Swiss father & 1638 & $\begin{array}{c}0.373 \\
(0.045)\end{array}$ & $\begin{array}{c}0.227 \\
(0.044)\end{array}$ & $\begin{array}{c}0.327 \\
(0.043) \\
{[0.868]}\end{array}$ & $\begin{array}{c}0.34 \\
(0.038) \\
{[0.849]}\end{array}$ & $\begin{array}{l}0.362 \\
(0.04) \\
{[0.303]}\end{array}$ \\
\hline Immigrant father & 500 & $\begin{array}{c}0.618 \\
(0.085)\end{array}$ & $\begin{array}{c}0.315 \\
(0.081)\end{array}$ & $\begin{array}{c}0.584 \\
(0.082) \\
{[0.410]}\end{array}$ & $\begin{array}{c}0.569 \\
(0.067) \\
{[0.980]}\end{array}$ & $\begin{array}{c}0.619 \\
(0.072) \\
{[0.279]}\end{array}$ \\
\hline
\end{tabular}

Note: All sons from the SHP 1999 - 2003. Standard errors are in parentheses. Standard errors adjusted using Rubin's method. All incomes are age adjusted. Numbers in brackets indicate t-values for the null hypothesis that parameters in column (4) - (6) are identical to those in column (2) using standard bootstrap method (Efron and Tibshirani 1993) 
Table 3 B Least squares estimation of $\rho$ by different specifications of the SHP - Elasticities

\begin{tabular}{|c|c|c|c|c|}
\hline & $\begin{array}{c}\text { excludes work interrupters, } \\
\text { highest/lowest incomes } \\
\text { part time job incomes extrapolated to } 100 \% \\
\text { (1) }\end{array}$ & $\begin{array}{l}\text { includes work interrupters, } \\
\text { highest/lowest incomes } \\
\text { (2) }\end{array}$ & $\begin{array}{l}\text { includes (2) and } \\
\text { real part time incomes } \\
\text { (3) }\end{array}$ & $\begin{array}{l}\text { includes (3) and } \\
\text { controlled for son's education } \\
\text { (4) }\end{array}$ \\
\hline All & $\begin{array}{c}0.455 \\
(0.041)\end{array}$ & $\begin{array}{c}0.441 \\
(0.043)\end{array}$ & $\begin{array}{c}0.442 \\
(0.043)\end{array}$ & $\begin{array}{c}0.266 \\
(0.041)\end{array}$ \\
\hline Swiss & $\begin{array}{c}0.382 \\
(0.048)\end{array}$ & $\begin{array}{c}0.37 \\
(0.05)\end{array}$ & $\begin{array}{c}0.375 \\
(0.051)\end{array}$ & $\begin{array}{c}0.216 \\
(0.049)\end{array}$ \\
\hline Immigrants & $\begin{array}{c}0.551 \\
(0.064)\end{array}$ & $\begin{array}{c}0.522 \\
(0.067)\end{array}$ & $\begin{array}{c}0.518 \\
(0.067)\end{array}$ & $\begin{array}{c}0.31 \\
(0.068)\end{array}$ \\
\hline S. E. Europe & $\begin{array}{c}0.219 \\
(0.166)\end{array}$ & $\begin{array}{c}0.112 \\
(0.181)\end{array}$ & $\begin{array}{c}0.106 \\
(0.188)\end{array}$ & $\begin{array}{c}0.04 \\
(0.198)\end{array}$ \\
\hline Italy & $\begin{array}{c}0.508 \\
(0.115)\end{array}$ & $\begin{array}{c}0.458 \\
(0.115)\end{array}$ & $\begin{array}{c}0.464 \\
(0.116)\end{array}$ & $\begin{array}{c}0.276 \\
(0.114)\end{array}$ \\
\hline Germany & $\begin{array}{c}0.186 \\
(0.164)\end{array}$ & $\begin{array}{c}0.205 \\
(0.149)\end{array}$ & $\begin{array}{c}0.202 \\
(0.149)\end{array}$ & $\begin{array}{c}0.126 \\
(0.153)\end{array}$ \\
\hline France & $\begin{array}{c}0.376 \\
(0.187)\end{array}$ & $\begin{array}{c}0.31 \\
(0.175)\end{array}$ & $\begin{array}{c}0.311 \\
(0.174)\end{array}$ & $\begin{array}{c}0.252 \\
(0.174)\end{array}$ \\
\hline Spain / Portugal & $\begin{array}{c}0.631 \\
(0.178)\end{array}$ & $\begin{array}{c}0.609 \\
(0.163)\end{array}$ & $\begin{array}{c}0.623 \\
(0.169)\end{array}$ & $\begin{array}{c}0.34 \\
(0.192)\end{array}$ \\
\hline Swiss father & $\begin{array}{c}0.373 \\
(0.045)\end{array}$ & $\begin{array}{c}0.359 \\
(0.048)\end{array}$ & $\begin{array}{c}0.362 \\
(0.048)\end{array}$ & $\begin{array}{c}0.214 \\
(0.047)\end{array}$ \\
\hline Immigrant father & $\begin{array}{c}0.618 \\
(0.085)\end{array}$ & $\begin{array}{c}0.584 \\
(0.086)\end{array}$ & $\begin{array}{c}0.589 \\
(0.087)\end{array}$ & $\begin{array}{c}0.313 \\
(0.079)\end{array}$ \\
\hline Total no. Obs. & 2138 & 2162 & 2162 & 2162 \\
\hline
\end{tabular}

Note: All sons from the SHP 1999 - 2003; all fathers from the SLFS 1991. Standard errors are in parentheses. Standard errors adjusted using Rubin's method. All incomes are age adjusted. 
Table 3 C Least squares estimation of $\rho$ by different subsamples of the SHP - Elasticities by age groups of the sons

\begin{tabular}{|c|c|c|c|c|}
\hline & All & age $25-35$ & age $36-45$ & age $46-55$ \\
\hline All & $\begin{array}{c}0.455 \\
(0.041) \\
\end{array}$ & $\begin{array}{c}0.306 \\
(0.062) \\
\end{array}$ & $\begin{array}{c}0.478 \\
(0.056) \\
\end{array}$ & $\begin{array}{c}0.55 \\
(0.071) \\
\end{array}$ \\
\hline No. obs. & 2138 & 658 & 792 & 688 \\
\hline Natives & $\begin{array}{c}0.382 \\
(0.048) \\
\end{array}$ & $\begin{array}{c}0.234 \\
(0.074) \\
\end{array}$ & $\begin{array}{c}0.413 \\
(0.069) \\
\end{array}$ & $\begin{array}{c}0.464 \\
(0.082) \\
\end{array}$ \\
\hline No. obs. & 1460 & 429 & 520 & 511 \\
\hline Immigrants & $\begin{array}{c}0.551 \\
(0.064) \\
\end{array}$ & $\begin{array}{c}0.358 \\
(0.1) \\
\end{array}$ & $\begin{array}{c}0.544 \\
(0.094) \\
\end{array}$ & $\begin{array}{l}0.745 \\
(0.12) \\
\end{array}$ \\
\hline No. obs. & 678 & 229 & 272 & 177 \\
\hline Native father & $\begin{array}{c}0.373 \\
(0.045) \\
\end{array}$ & $\begin{array}{c}0.205 \\
(0.071) \\
\end{array}$ & $\begin{array}{c}0.387 \\
(0.065) \\
\end{array}$ & $\begin{array}{c}0.483 \\
(0.077)\end{array}$ \\
\hline No. obs. & 1638 & 489 & 590 & 559 \\
\hline Immigrant father & $\begin{array}{c}0.618 \\
(0.085)\end{array}$ & $\begin{array}{c}0.508 \\
(0.126)\end{array}$ & $\begin{array}{c}0.621 \\
(0.116)\end{array}$ & $\begin{array}{c}0.728 \\
(0.146)\end{array}$ \\
\hline No. obs. & 500 & 169 & 202 & 129 \\
\hline
\end{tabular}

Note: All sons from the SHP 1999 - 2003; all fathers from the SLFS 1991. Standard errors are in parentheses. Standard errors

adjusted using Rubin's method. All incomes are age adjusted. 
Table 4 Descriptive analysis of intergenerational income mobility

Table 4 A Transition matrix for all individuals (in row percent)

\begin{tabular}{|c|c|c|c|c|c|}
\hline \multirow[b]{2}{*}{ Father } & \multicolumn{4}{|c|}{ Son's } & \multirow[b]{2}{*}{ No. obs } \\
\hline & $\begin{array}{l}\text { 1. quartile } \\
\text { (1) }\end{array}$ & $\begin{array}{l}\text { 2. quartile } \\
\text { (2) }\end{array}$ & $\begin{array}{l}\text { 3. quartile } \\
\text { (3) }\end{array}$ & $\begin{array}{l}\text { 4. quartile } \\
\text { (4) }\end{array}$ & \\
\hline 1. quartile & $39.60 \%$ & $27.88 \%$ & $16.97 \%$ & $15.56 \%$ & 495 \\
\hline 2. quartile & $27.81 \%$ & $28.98 \%$ & $24.12 \%$ & $19.10 \%$ & 597 \\
\hline 3. quartile & $16.63 \%$ & $24.58 \%$ & $29.88 \%$ & $28.92 \%$ & 415 \\
\hline 4. quartile & $13.63 \%$ & $17.40 \%$ & $30.19 \%$ & $38.78 \%$ & 477 \\
\hline No. Obs. & 496 & 496 & 496 & 496 & 1984 \\
\hline
\end{tabular}

Note: Immobility Index: 3.01. Description from the SHP $1999-2003$ before Multiple Imputation. All fathers from the SLFS 1991

Table 4 B Transition matrix for natives (in row percent)

\begin{tabular}{|c|c|c|c|c|c|}
\hline \multirow[b]{2}{*}{ Father } & \multicolumn{4}{|c|}{ Son's } & \multirow[b]{2}{*}{ No. obs } \\
\hline & $\begin{array}{l}\text { 1. quartile } \\
\text { (1) }\end{array}$ & $\begin{array}{l}\text { 2. quartile } \\
\text { (2) }\end{array}$ & $\begin{array}{l}\text { 3. quartile } \\
\text { (3) }\end{array}$ & $\begin{array}{l}\text { 4. quartile } \\
\text { (4) }\end{array}$ & \\
\hline 1. quartile & $37.46 \%$ & $25.07 \%$ & $20.06 \%$ & $17.40 \%$ & 339 \\
\hline 2. quartile & $28.83 \%$ & $29.09 \%$ & $21.56 \%$ & $20.52 \%$ & 385 \\
\hline 3. quartile & $17.06 \%$ & $27.42 \%$ & $29.77 \%$ & $25.75 \%$ & 299 \\
\hline 4. quartile & $15.06 \%$ & $18.07 \%$ & $29.82 \%$ & $37.05 \%$ & 332 \\
\hline No. Obs. & 339 & 339 & 339 & 338 & 1355 \\
\hline
\end{tabular}

Note: Immobility Index: 2.92. Description from the SHP $1999-2003$ before Multiple Imputation. All fathers from the SLFS 1991

Table $4 \mathrm{C}$ Transition matrix for immigrants (in row percent)

\begin{tabular}{|c|c|c|c|c|c|}
\hline \multirow[b]{2}{*}{ Father } & \multicolumn{4}{|c|}{ Son's } & \multirow[b]{2}{*}{ No. obs } \\
\hline & $\begin{array}{l}\text { 1. quartile } \\
\text { (1) }\end{array}$ & $\begin{array}{l}\text { 2. quartile } \\
\text { (2) }\end{array}$ & $\begin{array}{l}\text { 3. quartile } \\
\text { (3) }\end{array}$ & $\begin{array}{l}\text { 4. quartile } \\
\text { (4) }\end{array}$ & \\
\hline 1. quartile & $44.38 \%$ & $28.40 \%$ & $17.16 \%$ & $10.06 \%$ & 169 \\
\hline 2. quartile & $29.73 \%$ & $29.05 \%$ & $25.68 \%$ & $15.54 \%$ & 148 \\
\hline 3. quartile & $12.26 \%$ & $29.03 \%$ & $25.16 \%$ & $33.55 \%$ & 155 \\
\hline 4. quartile & $12.74 \%$ & $13.38 \%$ & $32.48 \%$ & $41.40 \%$ & 157 \\
\hline No. Obs. & 158 & 157 & 157 & 157 & 629 \\
\hline
\end{tabular}

Note: Immobility Index: 3.19. Description from the SHP $1999-2003$ before Multiple Imputation. All fathers from the SLFS 1991

Table 4 D Transition matrix for indiviuals with a native father (in row percent)

\begin{tabular}{|c|c|c|c|c|c|}
\hline \multirow[b]{2}{*}{ Father } & \multicolumn{4}{|c|}{ Son's } & \multirow[b]{2}{*}{ No. obs } \\
\hline & $\begin{array}{l}\text { 1. quartile } \\
\text { (1) }\end{array}$ & $\begin{array}{l}\text { 2. quartile } \\
\text { (2) }\end{array}$ & $\begin{array}{l}\text { 3. quartile } \\
\text { (3) }\end{array}$ & $\begin{array}{l}\text { 4. quartile } \\
\text { (4) }\end{array}$ & \\
\hline 1. quartile & $35.95 \%$ & $26.58 \%$ & $19.49 \%$ & $17.97 \%$ & 395 \\
\hline 2. quartile & $28.47 \%$ & $29.46 \%$ & $22.28 \%$ & $19.80 \%$ & 404 \\
\hline 3. quartile & $17.27 \%$ & $25.35 \%$ & $30.64 \%$ & $26.74 \%$ & 359 \\
\hline 4. quartile & $17.03 \%$ & $17.86 \%$ & $28.57 \%$ & $36.54 \%$ & 364 \\
\hline No. Obs. & 381 & 380 & 381 & 380 & 1522 \\
\hline
\end{tabular}

Note: Immobility Index: 2.91. Description from the SHP $1999-2003$ before Multiple Imputation. All fathers from the SLFS 1991 
Table 4 E Transition matrix for indiviuals with an immigrant father (in row percent)

\begin{tabular}{|c|c|c|c|c|c|}
\hline \multirow[b]{2}{*}{ Father } & \multicolumn{4}{|c|}{ Son's } & \multirow[b]{2}{*}{ No. obs. } \\
\hline & $\begin{array}{l}\text { 1. quartile } \\
\text { (1) }\end{array}$ & $\begin{array}{l}\text { 2. quartile } \\
\text { (2) }\end{array}$ & $\begin{array}{l}\text { 3. quartile } \\
\text { (3) }\end{array}$ & $\begin{array}{l}\text { 4. quartile } \\
\text { (4) }\end{array}$ & \\
\hline 1. quartile & $38.71 \%$ & $29.03 \%$ & $20.65 \%$ & $11.61 \%$ & 155 \\
\hline 2. quartile & $25.74 \%$ & $29.41 \%$ & $28.68 \%$ & $16.18 \%$ & 136 \\
\hline 3. quartile & $10.34 \%$ & $32.76 \%$ & $20.69 \%$ & $36.21 \%$ & 58 \\
\hline 4. quartile & $13.27 \%$ & $9.73 \%$ & $29.20 \%$ & $47.79 \%$ & 113 \\
\hline No. Obs. & 116 & 115 & 116 & 115 & 462 \\
\hline
\end{tabular}

Note: Immobility Index: 3.18. Description from the SHP 1999 - 2003 before Multiple Imputation. All fathers from the

SLFS 1991

Table 4 F Comparison of the ratios (highest vs lowest quartile)

\begin{tabular}{|c|c|c|c|c|c|c|c|}
\hline Father & $\begin{array}{c}\text { all individuals } \\
\text { (1) }\end{array}$ & $\begin{array}{c}\text { natives } \\
\text { (2) }\end{array}$ & $\begin{array}{c}\text { immigrants } \\
\text { (3) }\end{array}$ & $\begin{array}{l}\text { individuals with } \\
\text { native father } \\
\text { (4) }\end{array}$ & $\begin{array}{l}\text { individuals with } \\
\text { immigrant father } \\
\text { (5) }\end{array}$ & $\begin{array}{c}\text { natives vs. } \\
\text { immigrants } \\
(6) \\
(2)-(3)\end{array}$ & $\begin{array}{c}\text { native father vs } \\
\text { immigrant father } \\
(7) \\
(4)-(5)\end{array}$ \\
\hline 1. quartile & $\begin{array}{c}0.39 \\
(0.05)\end{array}$ & $\begin{array}{l}0.46 \\
(0.07)\end{array}$ & $\begin{array}{c}0.23 \\
(0.07)\end{array}$ & $\begin{array}{l}0.50 \\
(0.05)\end{array}$ & $\begin{array}{c}0.30 \\
(0.08)\end{array}$ & $\begin{array}{c}0.24 \\
(0.09)\end{array}$ & $\begin{array}{c}0.20 \\
(0.08)\end{array}$ \\
\hline 2. quartile & $\begin{array}{c}0.69 \\
(0.08)\end{array}$ & $\begin{array}{c}0.71 \\
(0.05)\end{array}$ & $\begin{array}{c}0.52 \\
(0.18)\end{array}$ & $\begin{array}{c}0.70 \\
(0.07)\end{array}$ & $\begin{array}{c}0.63 \\
(0.22)\end{array}$ & $\begin{array}{c}0.19 \\
(0.17)\end{array}$ & $\begin{array}{c}0.07 \\
(0.18)\end{array}$ \\
\hline 3. quartile & $\begin{array}{l}1.74 \\
(0.4)\end{array}$ & $\begin{array}{c}1.51 \\
(0.32)\end{array}$ & $\begin{array}{c}2.74 \\
(1.06)\end{array}$ & $\begin{array}{c}1.55 \\
(0.22)\end{array}$ & $\begin{array}{c}3.50 \\
(1.42)\end{array}$ & $\begin{array}{l}-1.23 \\
(0.81)\end{array}$ & $\begin{array}{l}-1.95 \\
(1.31)\end{array}$ \\
\hline 4. quartile & $\begin{array}{c}2.85 \\
(0.36)\end{array}$ & $\begin{array}{c}2.46 \\
(0.37)\end{array}$ & $\begin{array}{c}3.25 \\
(0.43)\end{array}$ & $\begin{array}{c}2.15 \\
(0.17)\end{array}$ & $\begin{array}{c}3.60 \\
(0.95)\end{array}$ & $\begin{array}{l}-0.79 \\
(0.64)\end{array}$ & $\begin{array}{l}-1.45 \\
(0.86)\end{array}$ \\
\hline
\end{tabular}

bootstrap method (Efron and Tibshirani 1993 ) 
Table 5 Quantile regressions - Coefficients by subsamples

\begin{tabular}{|c|c|c|c|c|c|}
\hline & All individuals & Natives & Immigrants & $\begin{array}{l}\text { Individuals with } \\
\text { native father }\end{array}$ & $\begin{array}{l}\text { Individuals with } \\
\text { immigrant father }\end{array}$ \\
\hline 0.1 & $\begin{array}{c}0.48 \\
(0.064)\end{array}$ & $\begin{array}{c}0.43 \\
(0.074)\end{array}$ & $\begin{array}{c}0.425 \\
(0.125)\end{array}$ & $\begin{array}{c}0.383 \\
(0.069)\end{array}$ & $\begin{array}{c}0.443 \\
(0.165)\end{array}$ \\
\hline 0.15 & $\begin{array}{c}0.478 \\
(0.052)\end{array}$ & $\begin{array}{c}0.423 \\
(0.064)\end{array}$ & $\begin{array}{c}0.508 \\
(0.095)\end{array}$ & $\begin{array}{c}0.376 \\
(0.064)\end{array}$ & $\begin{array}{c}0.576 \\
(0.132)\end{array}$ \\
\hline 0.2 & $\begin{array}{c}0.5 \\
(0.052)\end{array}$ & $\begin{array}{c}0.399 \\
(0.056)\end{array}$ & $\begin{array}{l}0.548 \\
(0.09)\end{array}$ & $\begin{array}{c}0.361 \\
(0.056)\end{array}$ & $\begin{array}{c}0.619 \\
(0.104)\end{array}$ \\
\hline 0.25 & $\begin{array}{c}0.504 \\
(0.049)\end{array}$ & $\begin{array}{c}0.398 \\
(0.068)\end{array}$ & $\begin{array}{c}0.569 \\
(0.082)\end{array}$ & $\begin{array}{c}0.382 \\
(0.059)\end{array}$ & $\begin{array}{c}0.628 \\
(0.097)\end{array}$ \\
\hline 0.3 & $\begin{array}{c}0.495 \\
(0.052)\end{array}$ & $\begin{array}{c}0.4 \\
(0.06)\end{array}$ & $\begin{array}{c}0.589 \\
(0.082)\end{array}$ & $\begin{array}{c}0.386 \\
(0.059)\end{array}$ & $\begin{array}{l}0.636 \\
(0.1)\end{array}$ \\
\hline 0.35 & $\begin{array}{c}0.488 \\
(0.049)\end{array}$ & $\begin{array}{c}0.385 \\
(0.053)\end{array}$ & $\begin{array}{c}0.603 \\
(0.081)\end{array}$ & $\begin{array}{l}0.386 \\
(0.05)\end{array}$ & $\begin{array}{c}0.638 \\
(0.107)\end{array}$ \\
\hline 0.4 & $\begin{array}{c}0.47 \\
(0.043)\end{array}$ & $\begin{array}{c}0.38 \\
(0.048)\end{array}$ & $\begin{array}{l}0.595 \\
(0.078)\end{array}$ & $\begin{array}{c}0.376 \\
(0.045)\end{array}$ & $\begin{array}{c}0.647 \\
(0.109)\end{array}$ \\
\hline 0.45 & $\begin{array}{c}0.449 \\
(0.045)\end{array}$ & $\begin{array}{c}0.363 \\
(0.047)\end{array}$ & $\begin{array}{l}0.603 \\
(0.077)\end{array}$ & $\begin{array}{c}0.354 \\
(0.042)\end{array}$ & $\begin{array}{c}0.666 \\
(0.103)\end{array}$ \\
\hline 0.5 & $\begin{array}{c}0.43 \\
(0.044)\end{array}$ & $\begin{array}{c}0.36 \\
(0.047)\end{array}$ & $\begin{array}{c}0.612 \\
(0.079)\end{array}$ & $\begin{array}{l}0.344 \\
(0.048)\end{array}$ & $\begin{array}{c}0.669 \\
(0.105)\end{array}$ \\
\hline 0.55 & $\begin{array}{c}0.432 \\
(0.044)\end{array}$ & $\begin{array}{c}0.354 \\
(0.052)\end{array}$ & $\begin{array}{l}0.604 \\
(0.077)\end{array}$ & $\begin{array}{c}0.347 \\
(0.049)\end{array}$ & $\begin{array}{c}0.667 \\
(0.106)\end{array}$ \\
\hline 0.6 & $\begin{array}{c}0.432 \\
(0.039)\end{array}$ & $\begin{array}{l}0.352 \\
(0.05)\end{array}$ & $\begin{array}{c}0.602 \\
(0.075)\end{array}$ & $\begin{array}{c}0.352 \\
(0.045)\end{array}$ & $\begin{array}{c}0.68 \\
(0.107)\end{array}$ \\
\hline 0.65 & $\begin{array}{c}0.431 \\
(0.048)\end{array}$ & $\begin{array}{c}0.336 \\
(0.051)\end{array}$ & $\begin{array}{c}0.607 \\
(0.077)\end{array}$ & $\begin{array}{c}0.336 \\
(0.052)\end{array}$ & $\begin{array}{c}0.737 \\
(0.109)\end{array}$ \\
\hline 0.7 & $\begin{array}{c}0.42 \\
(0.057)\end{array}$ & $\begin{array}{l}0.313 \\
(0.054)\end{array}$ & $\begin{array}{c}0.63 \\
(0.082)\end{array}$ & $\begin{array}{l}0.314 \\
(0.05)\end{array}$ & $\begin{array}{c}0.768 \\
(0.108)\end{array}$ \\
\hline 0.75 & $\begin{array}{c}0.431 \\
(0.054)\end{array}$ & $\begin{array}{c}0.319 \\
(0.069)\end{array}$ & $\begin{array}{c}0.651 \\
(0.093)\end{array}$ & $\begin{array}{c}0.338 \\
(0.055)\end{array}$ & $\begin{array}{c}0.772 \\
(0.119)\end{array}$ \\
\hline 0.8 & $\begin{array}{c}0.444 \\
(0.059)\end{array}$ & $\begin{array}{c}0.346 \\
(0.074)\end{array}$ & $\begin{array}{l}0.645 \\
(0.093)\end{array}$ & $\begin{array}{c}0.352 \\
(0.064)\end{array}$ & $\begin{array}{c}0.752 \\
(0.121)\end{array}$ \\
\hline 0.85 & $\begin{array}{c}0.471 \\
(0.067)\end{array}$ & $\begin{array}{c}0.379 \\
(0.088)\end{array}$ & $\begin{array}{c}0.592 \\
(0.101)\end{array}$ & $\begin{array}{c}0.392 \\
(0.079)\end{array}$ & $\begin{array}{c}0.676 \\
(0.138)\end{array}$ \\
\hline 0.9 & $\begin{array}{c}0.52 \\
(0.082)\end{array}$ & $\begin{array}{c}0.436 \\
(0.091)\end{array}$ & $\begin{array}{c}0.571 \\
(0.111)\end{array}$ & $\begin{array}{c}0.437 \\
(0.084)\end{array}$ & $\begin{array}{c}0.587 \\
(0.179)\end{array}$ \\
\hline No. Obs & 2138 & 1460 & 678 & 1638 & 500 \\
\hline
\end{tabular}

Note: All sons from the SHP 1999 - 2003; all fathers from the SLFS 1991. Standard errors are in parentheses. Standard errors adjusted using Rubin's method. All incomes are age adjusted. 
Table 6 Share of explained percentage of the intergenerational mobility by education

\begin{tabular}{c|ccccc}
\hline & All individuals & Natives & Immigrants & $\begin{array}{c}\text { Individuals with } \\
\text { native father }\end{array}$ & $\begin{array}{c}\text { Individuals with } \\
\text { immigrant father }\end{array}$ \\
\hline 0.1 & $26.04 \%$ & $33.02 \%$ & $23.29 \%$ & $31.07 \%$ & $27.54 \%$ \\
0.15 & $27.82 \%$ & $27.90 \%$ & $35.24 \%$ & $25.27 \%$ & $34.20 \%$ \\
0.2 & $34.20 \%$ & $27.32 \%$ & $38.87 \%$ & $28.81 \%$ & $36.19 \%$ \\
0.25 & $40.67 \%$ & $33.92 \%$ & $39.19 \%$ & $37.43 \%$ & $39.01 \%$ \\
0.3 & $41.82 \%$ & $41.75 \%$ & $42.78 \%$ & $40.16 \%$ & $40.88 \%$ \\
0.35 & $41.80 \%$ & $36.36 \%$ & $46.60 \%$ & $36.79 \%$ & $43.26 \%$ \\
0.4 & $38.72 \%$ & $32.63 \%$ & $46.89 \%$ & $35.37 \%$ & $50.70 \%$ \\
0.45 & $40.76 \%$ & $36.64 \%$ & $46.27 \%$ & $35.88 \%$ & $53.90 \%$ \\
0.5 & $40.23 \%$ & $38.89 \%$ & $50.00 \%$ & $39.24 \%$ & $57.55 \%$ \\
0.55 & $40.74 \%$ & $37.29 \%$ & $52.81 \%$ & $38.33 \%$ & $55.62 \%$ \\
0.6 & $37.50 \%$ & $34.94 \%$ & $54.32 \%$ & $34.66 \%$ & $54.12 \%$ \\
0.65 & $34.80 \%$ & $26.19 \%$ & $48.11 \%$ & $28.87 \%$ & $54.14 \%$ \\
0.7 & $36.19 \%$ & $26.52 \%$ & $44.44 \%$ & $29.30 \%$ & $52.86 \%$ \\
0.75 & $38.75 \%$ & $25.39 \%$ & $48.69 \%$ & $31.66 \%$ & $53.76 \%$ \\
0.8 & $39.41 \%$ & $37.86 \%$ & $48.37 \%$ & $35.80 \%$ & $52.79 \%$ \\
0.85 & $40.34 \%$ & $39.84 \%$ & $40.20 \%$ & $42.86 \%$ & $43.93 \%$ \\
0.9 & $30.19 \%$ & $36.93 \%$ & $39.58 \%$ & $28.15 \%$ & $38.67 \%$ \\
\hline Average & $37.06 \%$ & $33.73 \%$ & $43.86 \%$ & $34.10 \%$ & $46.42 \%$ \\
\hline Ne. & & & & \\
\hline
\end{tabular}

Note: All sons from the SHP 1999 - 2003; all fathers from the SLFS 1991.Values show the reduction of the intergenerational coefficients in percent due to the inclusion of education as a control in the quantile regression. 
Figure 1 A Quantile regression of son's on father's income - natives

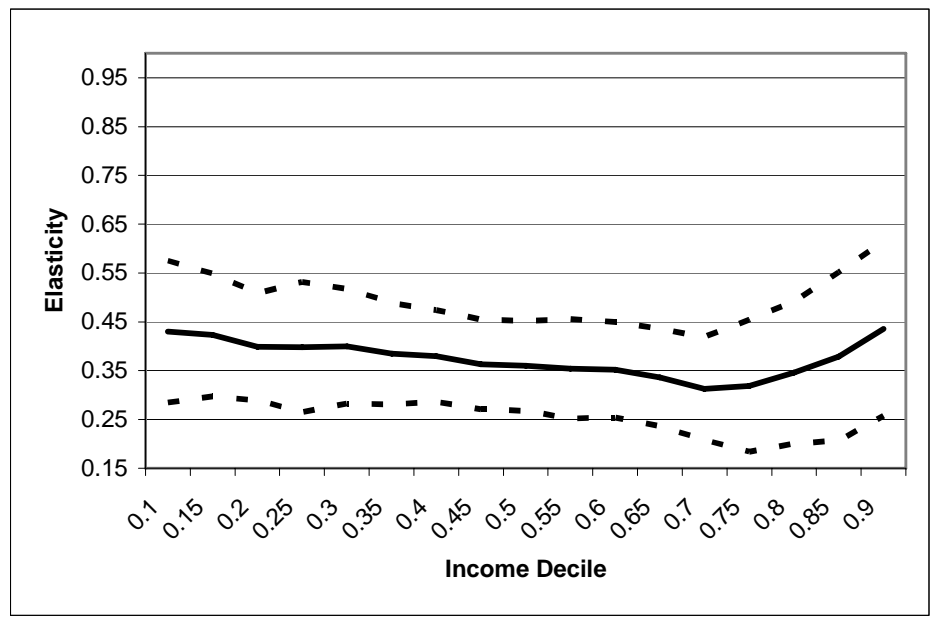

Note: dashed line indicates 95 percent confidence intervals of a t-distribution

Figure 1C Quantile regression of son's on father's income - individuals with native father

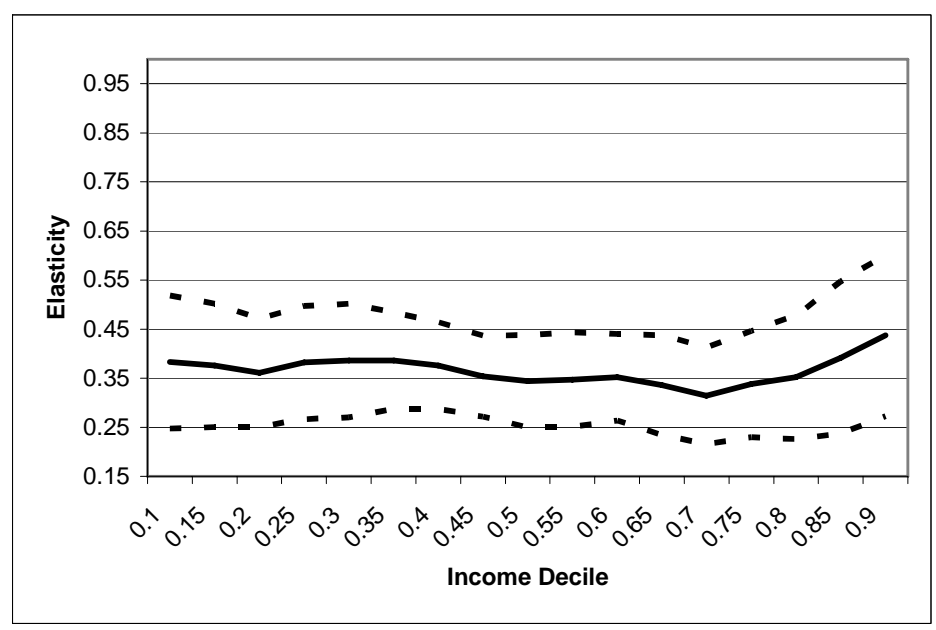

Note: dashed line indicates 95 percent confidence intervals of a t-distribution
Figure 1 B Quantile regression of son's on father's income - immigrants

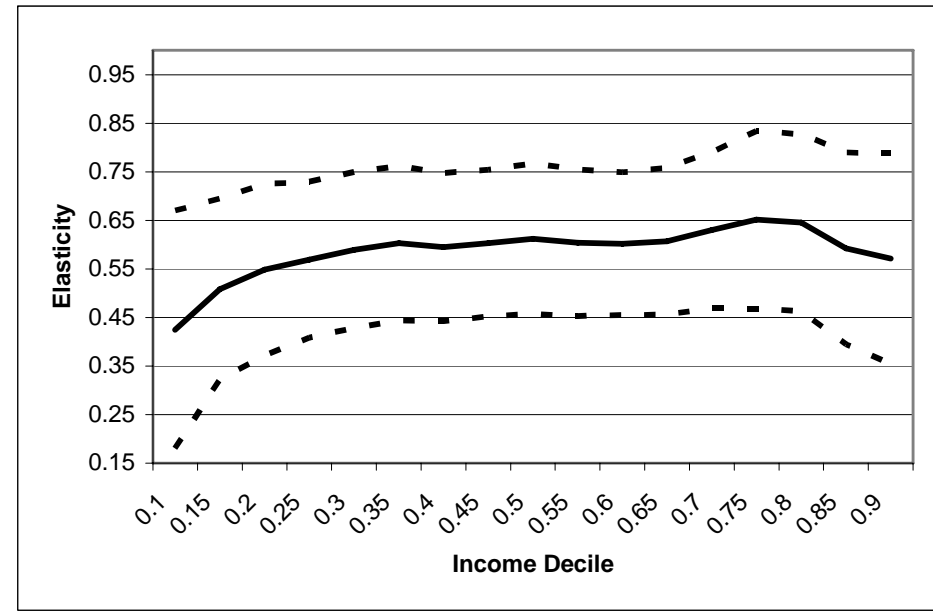

Note: dashed line indicates 95 percent confidence intervals of a t-distribution

Figure 1 D Quantile regression of son's on father's income - individuals with immigrants father

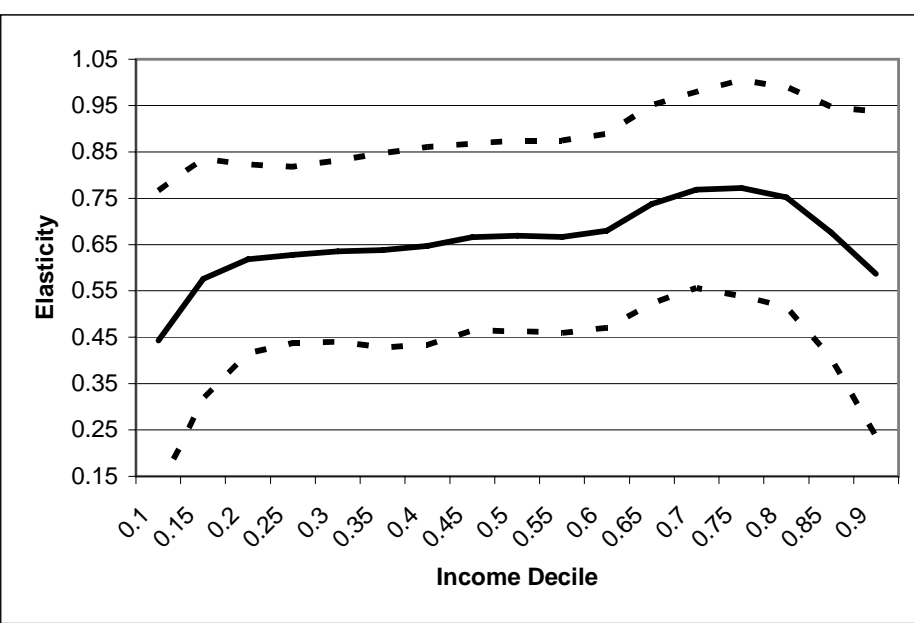

Note: dashed line indicates 95 percent confidence intervals of a t-distribution 
Appendix

Table A1 Father regression by subsamples - SLFS

\begin{tabular}{|c|c|c|c|c|}
\hline Variable & Sample 1991 & Sample 1998 & $\begin{array}{c}\text { All individuals } \\
\text { Sample } 1991-2003 \\
\end{array}$ & $\begin{array}{c}\text { Individuals } \\
\text { observed } 5 \text { years }\end{array}$ \\
\hline Legislators, senior officials, managers (0/1) & $\begin{array}{c}0.341 \\
(0.043)\end{array}$ & $\begin{array}{c}0.366 \\
(0.039)\end{array}$ & $\begin{array}{c}0.414 \\
(0.015)\end{array}$ & $\begin{array}{c}0.352 \\
(0.014)\end{array}$ \\
\hline Professionals (0/1) & $\begin{array}{c}0.306 \\
(0.041)\end{array}$ & $\begin{array}{c}0.294 \\
(0.038)\end{array}$ & $\begin{array}{c}0.333 \\
(0.016)\end{array}$ & $\begin{array}{c}0.304 \\
(0.013)\end{array}$ \\
\hline Technicians and associate professionals* $(0 / 1)$ & $\begin{array}{l}0.214 \\
(0.036)\end{array}$ & $\begin{array}{c}0.237 \\
(0.038)\end{array}$ & $\begin{array}{l}0.269 \\
(0.015)\end{array}$ & $\begin{array}{l}0.234 \\
(0.013)\end{array}$ \\
\hline Clercs (0/1) & $\begin{array}{l}0.195 \\
(0.039)\end{array}$ & $\begin{array}{c}0.146 \\
(0.039)\end{array}$ & $\begin{array}{l}0.195 \\
(0.015)\end{array}$ & $\begin{array}{l}0.204 \\
(0.014)\end{array}$ \\
\hline Service workers, market sales workers (0/1) & $\begin{array}{l}0.137 \\
(0.043)\end{array}$ & $\begin{array}{c}0.091 \\
(0.045)\end{array}$ & $\begin{array}{c}0.123 \\
(0.017)\end{array}$ & $\begin{array}{c}0.13 \\
(0.017)\end{array}$ \\
\hline Skilled agricultural and fishery workers (0/1) & $\begin{array}{l}-0.121 \\
(0.045)\end{array}$ & $\begin{array}{l}-0.168 \\
(0.046)\end{array}$ & $\begin{array}{l}-0.146 \\
(0.019)\end{array}$ & $\begin{array}{l}-0.152 \\
(0.014)\end{array}$ \\
\hline Craft and related trades workers (0/1) & $\begin{array}{c}0.088 \\
(0.036)\end{array}$ & $\begin{array}{l}0.076 \\
(0.04)\end{array}$ & $\begin{array}{l}0.095 \\
(0.014)\end{array}$ & $\begin{array}{l}0.075 \\
(0.013)\end{array}$ \\
\hline Plant and machine operater assemblers (0/1) & $\begin{array}{c}0.051 \\
(0.041)\end{array}$ & $\begin{array}{c}0.069 \\
(0.041)\end{array}$ & $\begin{array}{l}0.099 \\
(0.016)\end{array}$ & $\begin{array}{c}0.069 \\
(0.015)\end{array}$ \\
\hline Elementary vocational training $(0 / 1)$ & $\begin{array}{l}0.026 \\
(0.058)\end{array}$ & $\begin{array}{c}0.171 \\
(0.056)\end{array}$ & $\begin{array}{l}0.068 \\
(0.026)\end{array}$ & $\begin{array}{c}0.073 \\
(0.018)\end{array}$ \\
\hline School of commerce or general training school (0/1) & $\begin{array}{l}0.168 \\
(0.059)\end{array}$ & $\begin{array}{l}0.141 \\
(0.07)\end{array}$ & $\begin{array}{l}0.214 \\
(0.02)\end{array}$ & $\begin{array}{c}0.229 \\
(0.017)\end{array}$ \\
\hline Apprenticeship (0/1) & $\begin{array}{l}0.157 \\
(0.037)\end{array}$ & $\begin{array}{l}0.181 \\
(0.03)\end{array}$ & $\begin{array}{l}0.188 \\
(0.011)\end{array}$ & $\begin{array}{c}0.159 \\
(0.011)\end{array}$ \\
\hline $2 \mathrm{t} 3$ years: full time vocational school (0/1) & $\begin{array}{c}0.255 \\
(0.047)\end{array}$ & $\begin{array}{c}0.19 \\
(0.043)\end{array}$ & $\begin{array}{c}0.237 \\
(0.015)\end{array}$ & $\begin{array}{c}0.193 \\
(0.015)\end{array}$ \\
\hline Maturity, high school, or teacher's Training college (0/1) & $\begin{array}{l}0.219 \\
(0.048)\end{array}$ & $\begin{array}{l}0.238 \\
(0.04)\end{array}$ & $\begin{array}{l}0.259 \\
(0.017)\end{array}$ & $\begin{array}{l}0.267 \\
(0.015)\end{array}$ \\
\hline Fed certif, technical school (0/1) & $\begin{array}{c}0.33 \\
(0.042)\end{array}$ & $\begin{array}{l}0.304 \\
(0.032)\end{array}$ & $\begin{array}{c}0.334 \\
(0.012)\end{array}$ & $\begin{array}{c}0.297 \\
(0.012)\end{array}$ \\
\hline University (0/1) & $\begin{array}{c}0.377 \\
(0.044)\end{array}$ & $\begin{array}{c}0.451 \\
(0.036)\end{array}$ & $\begin{array}{c}0.44 \\
(0.014)\end{array}$ & $\begin{array}{c}0.41 \\
(0.013)\end{array}$ \\
\hline No swiss citizenship (0/1) & $\begin{array}{l}-0.033 \\
(0.061)\end{array}$ & $\begin{array}{l}-0.023 \\
(0.07)\end{array}$ & $\begin{array}{c}0.014 \\
(0.023)\end{array}$ & $\begin{array}{c}-0.02 \\
(0.027)\end{array}$ \\
\hline Interactions with No Swiss Citizenship & & & & \\
\hline Legislators, senior officials, managers (0/1) & $\begin{array}{l}-0.037 \\
(0.09)\end{array}$ & $\begin{array}{c}0.01 \\
(0.092)\end{array}$ & $\begin{array}{l}0.048 \\
(0.026)\end{array}$ & $\begin{array}{l}0.042 \\
(0.04)\end{array}$ \\
\hline Professionals (0/1) & $\begin{array}{l}-0.084 \\
(0.069)\end{array}$ & $\begin{array}{l}-0.048 \\
(0.09)\end{array}$ & $\begin{array}{c}0.004 \\
(0.025)\end{array}$ & $\begin{array}{c}0.029 \\
(0.031)\end{array}$ \\
\hline Technicians and associate professionals* $(0 / 1)$ & $\begin{array}{l}-0.045 \\
(0.065)\end{array}$ & $\begin{array}{l}0.031 \\
(0.08)\end{array}$ & $\begin{array}{c}0 \\
(0.026)\end{array}$ & $\begin{array}{l}-0.008 \\
(0.031)\end{array}$ \\
\hline Clercs (0/1) & $\begin{array}{l}-0.173 \\
(0.077)\end{array}$ & $\begin{array}{l}-0.053 \\
(0.09)\end{array}$ & $\begin{array}{c}-0.119 \\
(0.027)\end{array}$ & $\begin{array}{c}-0.124 \\
(0.033)\end{array}$ \\
\hline Service workers, market sales workers $(0 / 1)$ & $\begin{array}{c}-0.21 \\
(0.075)\end{array}$ & $\begin{array}{l}-0.091 \\
(0.086)\end{array}$ & $\begin{array}{c}-0.13 \\
(0.025)\end{array}$ & $\begin{array}{l}-0.129 \\
(0.034)\end{array}$ \\
\hline Skilled agricultural and fishery workers (0/1) & $\begin{array}{c}0.02 \\
(0.135)\end{array}$ & $\begin{array}{c}0.152 \\
(0.124)\end{array}$ & $\begin{array}{c}0.085 \\
(0.041)\end{array}$ & $\begin{array}{c}0.116 \\
(0.045)\end{array}$ \\
\hline Craft and related trades workers $(0 / 1)$ & $\begin{array}{l}-0.038 \\
(0.061)\end{array}$ & $\begin{array}{c}0.023 \\
(0.075)\end{array}$ & $\begin{array}{l}-0.007 \\
(0.023)\end{array}$ & $\begin{array}{l}-0.004 \\
(0.027)\end{array}$ \\
\hline Plant and machine operater assemblers (0/1) & $\begin{array}{l}-0.013 \\
(0.07)\end{array}$ & $\begin{array}{c}-0.052 \\
(0.081)\end{array}$ & $\begin{array}{l}-0.037 \\
(0.025)\end{array}$ & $\begin{array}{l}-0.075 \\
(0.033)\end{array}$ \\
\hline Elementary vocational training $(0 / 1)$ & $\begin{array}{c}0.04 \\
(0.083)\end{array}$ & $\begin{array}{l}-0.154 \\
(0.119)\end{array}$ & $\begin{array}{l}-0.018 \\
(0.032)\end{array}$ & $\begin{array}{l}-0.084 \\
(0.033)\end{array}$ \\
\hline School of commerce or general training school (0/1) & $\begin{array}{l}-0.021 \\
(0.154)\end{array}$ & $\begin{array}{c}-0.189 \\
(0.175)\end{array}$ & $\begin{array}{c}-0.094 \\
(0.039)\end{array}$ & $\begin{array}{c}-0.077 \\
(0.041)\end{array}$ \\
\hline Apprenticeship (0/1) & $\begin{array}{l}-0.002 \\
(0.055)\end{array}$ & $\begin{array}{l}-0.058 \\
(0.051)\end{array}$ & $\begin{array}{c}-0.069 \\
(0.015)\end{array}$ & $\begin{array}{l}-0.043 \\
(0.016)\end{array}$ \\
\hline $2 \mathrm{t} 3$ years: full time vocational school (0/1) & $\begin{array}{c}0.052 \\
(0.086)\end{array}$ & $\begin{array}{l}-0.098 \\
(0.085)\end{array}$ & $\begin{array}{l}-0.118 \\
(0.023)\end{array}$ & $\begin{array}{c}-0.02 \\
(0.033)\end{array}$ \\
\hline Maturity, high school, or teacher's Training college (0/1) & $\begin{array}{c}-0.07 \\
(0.085)\end{array}$ & $\begin{array}{l}-0.015 \\
(0.095)\end{array}$ & $\begin{array}{l}-0.115 \\
(0.023)\end{array}$ & $\begin{array}{c}-0.131 \\
(0.027)\end{array}$ \\
\hline Fed certif, technical school (0/1) & $\begin{array}{l}-0.057 \\
(0.062)\end{array}$ & $\begin{array}{l}-0.019 \\
(0.062)\end{array}$ & $\begin{array}{l}-0.096 \\
(0.02)\end{array}$ & $\begin{array}{c}-0.064 \\
(0.021)\end{array}$ \\
\hline University (0/1) & $\begin{array}{c}0.02 \\
(0.069)\end{array}$ & $\begin{array}{l}-0.029 \\
(0.079)\end{array}$ & $\begin{array}{l}-0.071 \\
(0.02)\end{array}$ & $\begin{array}{c}-0.075 \\
(0.025)\end{array}$ \\
\hline Intercept & $\begin{array}{c}10.58 \\
(0.044)\end{array}$ & $\begin{array}{l}10.489 \\
(0.046)\end{array}$ & $\begin{array}{l}10.459 \\
(0.016)\end{array}$ & $\begin{array}{l}10.563 \\
(0.016)\end{array}$ \\
\hline R2 & 0.23586 & 0.26625 & 0.26556 & 0.37656 \\
\hline
\end{tabular}

Note: Regression on age adjusted incomes, results from multiple imputation. Standard errors are in parentheses.. 
Table A2 Quantile regressions with control for education - Coefficients by subsamples

\begin{tabular}{|c|c|c|c|c|c|}
\hline & All individuals & Natives & Immigrants & $\begin{array}{l}\text { Individuals with } \\
\text { native father }\end{array}$ & $\begin{array}{l}\text { Individuals with } \\
\text { immigrant father }\end{array}$ \\
\hline 0.1 & $\begin{array}{c}0.355 \\
(0.065)\end{array}$ & $\begin{array}{c}0.288 \\
(0.081)\end{array}$ & $\begin{array}{c}0.326 \\
(0.128)\end{array}$ & $\begin{array}{c}0.264 \\
(0.069)\end{array}$ & $\begin{array}{c}0.321 \\
(0.188)\end{array}$ \\
\hline 0.15 & $\begin{array}{l}0.345 \\
(0.057)\end{array}$ & $\begin{array}{c}0.305 \\
(0.065)\end{array}$ & $\begin{array}{l}0.329 \\
(0.106)\end{array}$ & $\begin{array}{c}0.281 \\
(0.063)\end{array}$ & $\begin{array}{c}0.379 \\
(0.153)\end{array}$ \\
\hline 0.2 & $\begin{array}{c}0.329 \\
(0.056)\end{array}$ & $\begin{array}{c}0.29 \\
(0.059)\end{array}$ & $\begin{array}{c}0.335 \\
(0.104)\end{array}$ & $\begin{array}{c}0.257 \\
(0.054)\end{array}$ & $\begin{array}{c}0.395 \\
(0.125)\end{array}$ \\
\hline 0.25 & $\begin{array}{c}0.299 \\
(0.051)\end{array}$ & $\begin{array}{c}0.263 \\
(0.055)\end{array}$ & $\begin{array}{c}0.346 \\
(0.083)\end{array}$ & $\begin{array}{c}0.239 \\
(0.054)\end{array}$ & $\begin{array}{c}0.383 \\
(0.104)\end{array}$ \\
\hline 0.3 & $\begin{array}{c}0.288 \\
(0.048)\end{array}$ & $\begin{array}{l}0.233 \\
(0.058)\end{array}$ & $\begin{array}{c}0.337 \\
(0.081)\end{array}$ & $\begin{array}{c}0.231 \\
(0.054)\end{array}$ & $\begin{array}{l}0.376 \\
(0.104)\end{array}$ \\
\hline 0.35 & $\begin{array}{c}0.284 \\
(0.039)\end{array}$ & $\begin{array}{l}0.245 \\
(0.054)\end{array}$ & $\begin{array}{c}0.322 \\
(0.092)\end{array}$ & $\begin{array}{c}0.244 \\
(0.048)\end{array}$ & $\begin{array}{c}0.362 \\
(0.109)\end{array}$ \\
\hline 0.4 & $\begin{array}{c}0.288 \\
(0.044)\end{array}$ & $\begin{array}{l}0.256 \\
(0.05)\end{array}$ & $\begin{array}{c}0.316 \\
(0.076)\end{array}$ & $\begin{array}{c}0.243 \\
(0.046)\end{array}$ & $\begin{array}{c}0.319 \\
(0.102)\end{array}$ \\
\hline 0.45 & $\begin{array}{c}0.266 \\
(0.042)\end{array}$ & $\begin{array}{c}0.23 \\
(0.045)\end{array}$ & $\begin{array}{c}0.324 \\
(0.076)\end{array}$ & $\begin{array}{c}0.227 \\
(0.043)\end{array}$ & $\begin{array}{l}0.307 \\
(0.09)\end{array}$ \\
\hline 0.5 & $\begin{array}{c}0.257 \\
(0.042)\end{array}$ & $\begin{array}{c}0.22 \\
(0.047)\end{array}$ & $\begin{array}{c}0.306 \\
(0.068)\end{array}$ & $\begin{array}{c}0.209 \\
(0.045)\end{array}$ & $\begin{array}{c}0.284 \\
(0.095)\end{array}$ \\
\hline 0.55 & $\begin{array}{c}0.256 \\
(0.037)\end{array}$ & $\begin{array}{c}0.222 \\
(0.044)\end{array}$ & $\begin{array}{c}0.285 \\
(0.065)\end{array}$ & $\begin{array}{c}0.214 \\
(0.038)\end{array}$ & $\begin{array}{c}0.296 \\
(0.094)\end{array}$ \\
\hline 0.6 & $\begin{array}{c}0.27 \\
(0.039)\end{array}$ & $\begin{array}{l}0.229 \\
(0.05)\end{array}$ & $\begin{array}{c}0.275 \\
(0.063)\end{array}$ & $\begin{array}{c}0.23 \\
(0.046)\end{array}$ & $\begin{array}{c}0.312 \\
(0.088)\end{array}$ \\
\hline 0.65 & $\begin{array}{c}0.281 \\
(0.045)\end{array}$ & $\begin{array}{l}0.248 \\
(0.06)\end{array}$ & $\begin{array}{c}0.315 \\
(0.066)\end{array}$ & $\begin{array}{l}0.239 \\
(0.05)\end{array}$ & $\begin{array}{l}0.338 \\
(0.09)\end{array}$ \\
\hline 0.7 & $\begin{array}{c}0.268 \\
(0.045)\end{array}$ & $\begin{array}{c}0.23 \\
(0.056)\end{array}$ & $\begin{array}{c}0.35 \\
(0.068)\end{array}$ & $\begin{array}{c}0.222 \\
(0.053)\end{array}$ & $\begin{array}{c}0.362 \\
(0.087)\end{array}$ \\
\hline 0.75 & $\begin{array}{c}0.264 \\
(0.047)\end{array}$ & $\begin{array}{l}0.238 \\
(0.057)\end{array}$ & $\begin{array}{c}0.334 \\
(0.074)\end{array}$ & $\begin{array}{c}0.231 \\
(0.049)\end{array}$ & $\begin{array}{c}0.357 \\
(0.099)\end{array}$ \\
\hline 0.8 & $\begin{array}{c}0.269 \\
(0.057)\end{array}$ & $\begin{array}{l}0.215 \\
(0.06)\end{array}$ & $\begin{array}{c}0.333 \\
(0.103)\end{array}$ & $\begin{array}{l}0.226 \\
(0.06)\end{array}$ & $\begin{array}{c}0.355 \\
(0.121)\end{array}$ \\
\hline 0.85 & $\begin{array}{c}0.281 \\
(0.056)\end{array}$ & $\begin{array}{c}0.228 \\
(0.081)\end{array}$ & $\begin{array}{l}0.354 \\
(0.12)\end{array}$ & $\begin{array}{c}0.224 \\
(0.079)\end{array}$ & $\begin{array}{c}0.379 \\
(0.159)\end{array}$ \\
\hline 0.9 & $\begin{array}{c}0.363 \\
(0.072)\end{array}$ & $\begin{array}{c}0.275 \\
(0.088)\end{array}$ & $\begin{array}{l}0.345 \\
(0.13)\end{array}$ & $\begin{array}{l}0.314 \\
(0.09)\end{array}$ & $\begin{array}{c}0.36 \\
(0.173)\end{array}$ \\
\hline No. Obs & 2138 & 1460 & 678 & 1638 & 500 \\
\hline
\end{tabular}

Note: All sons from the SHP 1999 - 2003; all fathers from the SLFS 1991. Standard errors are in parentheses. Standard errors adjusted using Rubin's method. All incomes are age adjusted. 
Figure A1 A Quantile regression of son's on father's income with control for education - natives

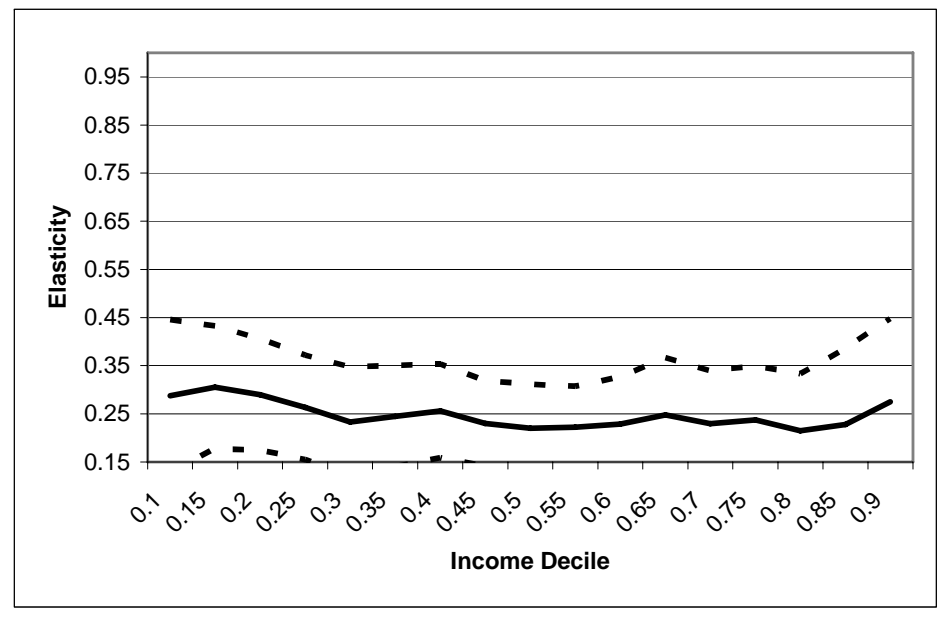

Note: dashed line indicates 95 percent confidence intervals of a t-distribution

\section{Figure A1 C Quantile regression of son's on father's income} with control for education - individuals with native father

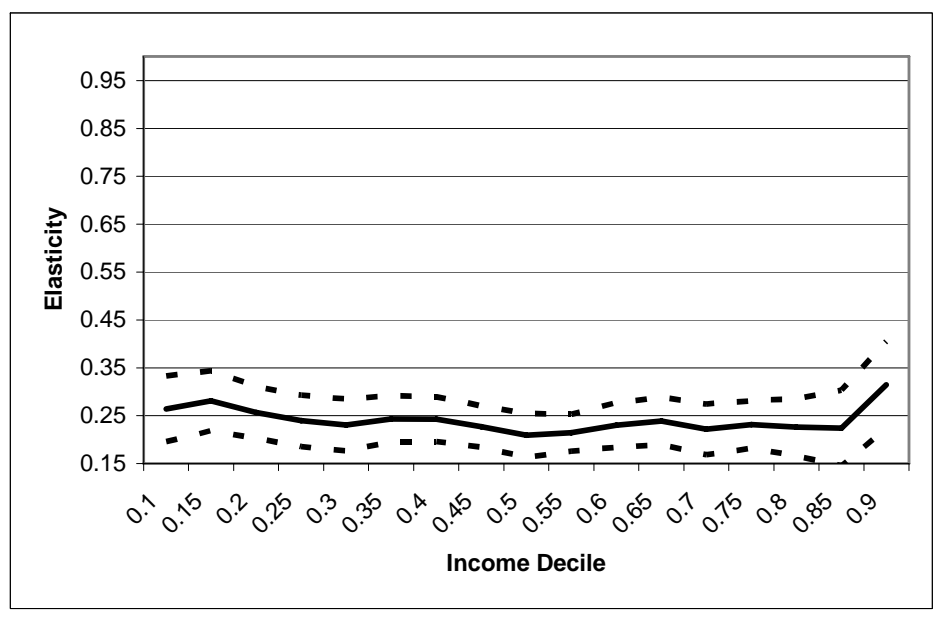

Note: dashed line indicates 95 percent confidence intervals of a t-distribution
Figure A1 B Quantile regression of son's on father's income with control for education - immigrants

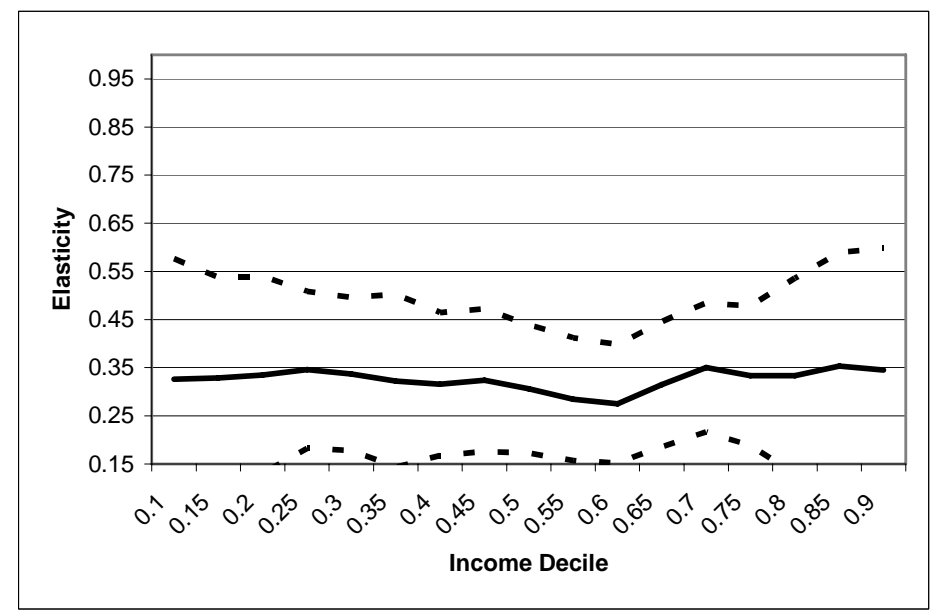

Note: dashed line indicates 95 percent confidence intervals of a t-distribution

\section{Figure A1 D Quantile regression of son's on father's income} with control for education - individuals with immigrants father

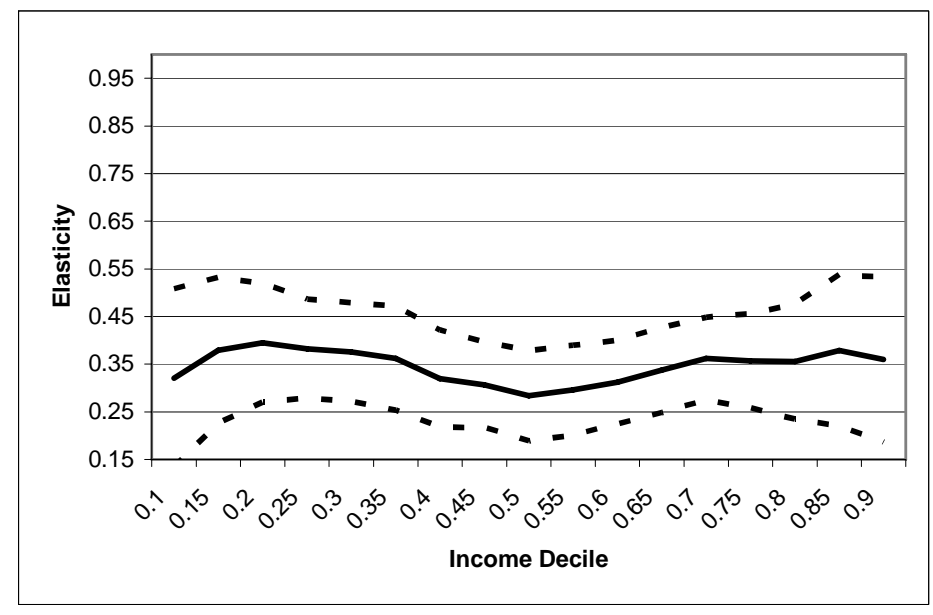

Note: dashed line indicates 95 percent confidence intervals of a t-distribution 